MÜHELYTANULMÁNYOK

DISCUSSION PAPERS

MT-DP - 2015/54

Various approaches to measuring business innovation: their relevance for capturing social innovation

ATTILA HAVAS 
Discussion papers

MT-DP - 2015/54

Institute of Economics, Centre for Economic and Regional Studies, Hungarian Academy of Sciences

KTI/IE Discussion Papers are circulated to promote discussion and provoque comments. Any references to discussion papers should clearly state that the paper is preliminary. Materials published in this series may subject to further publication.

Various approaches to measuring business innovation: their relevance for capturing social innovation

Author:

Attila Havas

senior research fellow

Institute of Economics - Centre for Economic and Regional Studies

Hungarian Academy of Sciences

e-mail: havas.attila@krtk.mta.hu

November 2015

ISBN 978-615-5594-22-9

ISSN $1785377 \mathrm{X}$ 


\title{
Various approaches to measuring business innovation: their relevance for capturing social innovation
}

\author{
Attila Havas
}

\section{Abstract}

This paper reviews various approaches to measuring business innovation from the angle of capturing social innovations and offers several methodological and policy conclusions. First, the Innovation Union Scoreboard (IUS) indicators in principle could be useful in settings where the dominant mode of innovation is based on R\&D activities. In practice, however, both R\&D and non-R\&D-based modes of innovation are fairly important. IUS, therefore, only provides a partial picture. Social innovations can certainly rely on R\&D-based technological innovations. Their essence, however, tends to be organisational, managerial and behavioural changes. The IUS indicators do not capture these types of changes. Second, an assessment of the 81 indicators used to compile the Global Innovation Index reveals that it would neither be a fruitful effort to rely on those indicators to capture social innovations. Third, given the diversity among innovation systems, a poor performance signalled by a composite indicator does not automatically identify the area(s) necessitating the most urgent policy actions. Only tailored, thorough comparative analyses can do so. Fourth, analysts and policy-makers need to be aware of the differences between measuring (i) social innovation activities (efforts) themselves, (ii) the framework conditions (pre-requisites, available inputs, skills, norms, values, behavioural patterns, etc.) of being socially innovative, and (iii) the economic, societal or environmental impacts of social innovations.

Keywords: Evolutionary economics of innovation; Business innovation; Social innovation; Measurement of innovation; Composite indicators; Scoreboards, league tables; Unit of analysis

Journal of Economic Literature (JEL): B52, C80, 031, O35, O38, Y10 Acknowledgments

This paper draws on work conducted for the CrESSI, Creating Economic Space for Social Innovation project that has received funding from the European Union's Seventh Framework Programme for Research, Technological Development and Demonstration (grant agreement No. 613261). 


\title{
Az üzleti célú innovációk mérése: kiterjeszthetjük-e ezeket a módszereket a társadalmi innovációk elemzésére?
}

\author{
Havas Attila
}

\section{Összefoglaló}

A tanulmány abból a szemszögből tekinti át az üzleti célú innovációk mérésére széles körben használt különböző módszereket, hogy azok milyen mértékben (lennének) alkalmasak a társadalmi innovációk elemzésére. A tanulmány következtetései szerint: 1) Az Innovációs Unió Eredménytábla (Innovation Union Scoreboard, IUS) összeállításához használt mérőszámok többsége a $\mathrm{K}+\mathrm{F}$ alapú innovációs folyamatokat méri. A gyakorlati tudásra támaszkodó innovációk azonban legalább ilyen fontosak a vállalatok számára, ezért az IUS csak részleges képet ad az innovációs teljesítményről. Bár a társadalmi innovációk $\mathrm{K}+\mathrm{F}$ eredményeket is hasznosíthatnak, a legtöbb esetben a döntő mozzanat egy új múködési mód bevezetése, illetve az ehhez szükséges szervezeti, vezetési és magatartásbeli változások. Ez utóbbiak megragadására nem alkalmasak az IUS mutatószámai. 2) A Globális Innovációs Index kiszámításához használt 81 mutató közül egyiket sem érdemes átvenni a társadalmi innovációk mérésére. 3) A számított (kompozit) mutatók csak korlátozottan alkalmasak az egymástól jelentősen eltérő innovációs rendszerek teljesítményének elemzésére: egy ilyen mutató alacsony szintje nem elégséges annak megállapítására, hogy melyik alrendszerben és milyen típusú szakpolitikai intézkedés szükséges. Az elégtelen teljesítmény okait és a kilábalás lehetőségeit alapos nemzetközi összehasonlító elemzésekkel lehet feltárni. 4) A társadalmi innovációk elemzése során is meg kell különböztetni, hogy mi a megfigyelés tárgya: (i) az innovációs tevékenységek (erőfeszítések) szintje; (ii) a társadalmi innovációk keretfeltételei (az erőforrások, a társadalmi innovációhoz szükséges tudás és gyakorlati tapasztalat megléte, az értékrend, a magatartásminták jellege stb.); vagy (iii) a társadalmi innovációk gazdasági, társadalmi és környezeti hatása.

Tárgyszavak: Az innováció evolúciós közgazdaságtana, Üzleti innováció; Társadalmi innováció; Az innováció mérése; Összetett (kompozit) mutatók; Eredménytáblák, rangsorok; A mérés tárgya

Journal of Economic Literature (JEL): B52, C80, O31, O35, O38, Y10 Köszönetnyilvánítás

A tanulmányt megalapozó kutatást a CrESSI, Creating Economic Space for Social Innovation (EU RTD FP7, No. 613261) projekt tette lehetővé. 


\section{Table of Contents}

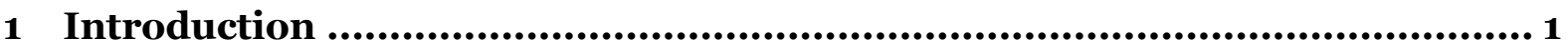

2 Models and economic theories of innovation........................................2

2.1 Linear, networked and interactive learning models of innovation and policy

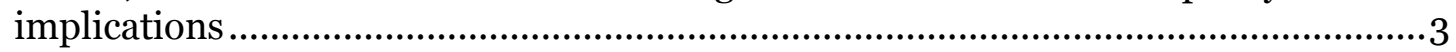

2.2 Innovation in economics paradigms ........................................................................ 5

2.3 Policy rationales derived from economic theories …................................................... 7

3 The Innovation Union Scoreboard........................................................ 10

4 The Global Innovation Index ...........................................................17

5 Further methodological considerations................................................24

5.1 Degree of novelty, unit of analysis ........................................................................24

5.2 Innovation activities, their framework conditions and impacts ................................26

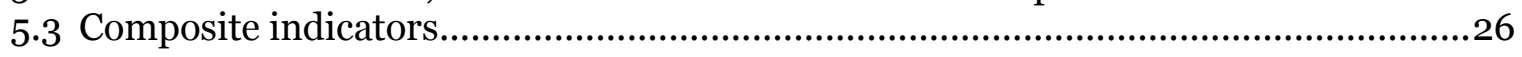

6 Summary and conclusions............................................................... 27

References ...............................................................................................30

Appendix 1: Sources of information for innovation ..................................36

Appendix 2: The EIS and IUS indicators .............................................38

Appendix 3: The Global Innovation Index indicators ..............................46 


\section{INTRODUCTION}

The basic objective of this paper is to review established approaches to capturing and measuring various types of innovations from the angle of measuring social innovations. Social innovation is defined by the CrESSI project as follows: "The development and delivery of new ideas (products, services, models, markets, processes) at different socio-structural levels that intentionally seek to improve human capabilities, social relations, and the processes in which these solutions are carried out." It is important to clarify at the outset that this paper considers all sorts of business (or: profit-oriented) innovations on the one hand, and social (socially-oriented or societal) innovations, on the other, irrespective of their nature. In other words, we should take into account not only technological (product, service, and process) innovations when discussing profit-oriented innovations, but organisational and marketing innovations as well. ${ }^{1}$ Innovation studies also show that it is more of an exception than a rule to introduce technological innovations without organisational innovations and in many cases marketing and market innovations are also needed. Moreover, the latter ones are vital for the success of the former ones. (Pavitt, 1999; Tidd et al., 1997) In particular, radical innovations often create new markets and that is, by definition, a market innovation as well.

In a similar vein, technological innovations, aimed at tackling societal challenges, should not be neglected when considering social innovations. Further, most likely certain organisational and marketing innovations might also be useful - or even indispensible - to achieve societal goals. In sum, we should keep in mind a distinction between the nature of innovations (technological, organisational, and marketing) and the goals of innovation efforts (business vs. societal purposes).

Significant progress has been achieved in measuring R\&D and innovation activities since the 1960s (Grupp, 1998; Grupp and Schubert, 2010; Smith, 2005) with the intention to provide comparable data sets as a solid basis for assessing R\&D and innovation performance and thereby guiding policy-makers in devising appropriate policies. ${ }^{2}$ Although there are widely used guidelines to collect data on $\mathrm{R} \& \mathrm{D}$ and innovation - the Frascati and Oslo Manuals (OECD, 2002 and 2005, respectively) -, it is not straightforward to find the most

\footnotetext{
${ }^{1}$ These three types of innovations are defined by the Oslo Manual (OECD, 2005), aimed at providing guidelines to interpret and measure innovations introduced by businesses. Interestingly, market innovations, that is, entering new markets to purchase inputs or sell outputs (not to be confused with marketing innovations) are not mentioned by the Manual (although these are parts of the classic description of innovation by Schumpeter, and important ones, indeed). Perhaps it would be almost impossible to measure these crucial innovations. Further financial innovations are not mentioned either as a separate category. Certain types of financial innovations can be interpreted as service innovations (e.g. new financial 'products'), while others (e.g. e- and m-banking) as new business practices, that is, organisational innovations using the definitions presented in the Manual.

2 "The Innovation Union Scoreboard 2013 gives a comparative assessment of the innovation performance of the EU27 Member States and the relative strengths and weaknesses of their research and innovation systems." (EC, 2013a: 4)
} 
appropriate way to assess $\mathrm{R} \& \mathrm{D}$ and innovation performance. To start with, $\mathrm{R} \& \mathrm{D}$ is such a complex, multifaceted process that it cannot be sufficiently characterised by two or three indicators, and that applies to innovation a fortiori. Hence, there is always a need to select a certain set of indicators to depict innovation processes, and especially to analyse and assess innovation performance. The choice of indicators is, therefore, an important decision reflecting the mindset of those decision-makers who have chosen them. These figures are 'subjective' in that respect, but as they are expressed in numbers, most people perceive indicators as being 'objective' by definition.

For this reason - besides several others - it is important to review how innovation is understood in particular models of innovations and analysed by various schools of economics. (Section 2) Based on this, two major measurement endeavours, namely the Innovation Union Scoreboard and the Global Innovation Index can be assessed in depth. (Sections 3-4) Further methodological issues are discussed in Section 5, while conclusions are summarised in Section 6.

\section{MODELS AND ECONOMIC THEORIES OF INNOVATION}

Besides Schumpeter, only a few economists had perceived innovation as a relevant research theme in the first half of the $20^{\text {th }}$ century. ${ }^{3}$ At that time, however, natural scientists, managers of business R\&D labs and policy advisors had formulated the first models of innovations - stressing the importance of scientific research -, and these ideas are still

highly influential. ${ }^{4}$ Since the late 1950s, more and more economists have shown interest in studying innovation, leading to new models of innovation, as well as an explicit mention of innovation in various economics paradigms. The role of innovation in economic development, however, is analysed by various schools of economics in diametrically different ways. 5 The underlying assumptions and key notions of these paradigms lead to diverse policy implications.

\footnotetext{
3 This section heavily draws on Section 2 in Havas (2015a).

4 For further details, see, e.g. Fagerberg et al. (2011: 898) and Godin (2008: 64-66).

5 The ensuing overview can only be brief, and thus somewhat simplified. More detailed and nuanced accounts, major achievements and synthesising pieces of work include Baumol (2002); Baumol et al. (2007); Castellacci (2008a); Dodgson and Rothwell (eds) (1994); Dodgson et al. (eds) (2014); Dosi (1988a), (1988b); Dosi et al. (eds) (1988); Edquist (ed.) (1997); Ergas (1986), (1987); Fagerberg et al. (eds) (2005); Fagerberg et al. (2012); Freeman (1994); Freeman and Soete (1997); Grupp (1998); Hall and Rosenberg (eds) (2010); Klevorick et al. (1995); Laestadious et al. (2005); Lazonick (2013); Lundvall (ed.) (1992); Lundvall and Borrás (1999); Martin (2012); Metcalfe (1998); Mowery and Nelson (1999); Nelson (ed.) (1993); Nelson (1995); OECD (1992), (1998); Pavitt (1999); Smith (2000); and von Tunzelman (1995).
} 


\subsection{LINEAR, NETWORKED AND INTERACTIVE LEARNING MODELS OF INNOVATION AND POLICY IMPLICATIONS}

The first models of innovation had been devised by natural scientists and practitioners before economists showed a serious interest in these issues. ${ }^{6}$ The idea that basic research is the main source of innovation had already been proposed at the beginning of the $20^{\text {th }}$ century, gradually leading to what is known today as the science-push model of innovation, forcefully advocated by Bush (1945).

It is worth recalling some of the main building blocks of Bush's reasoning:

"We will not get ahead in international trade unless we offer new and more attractive and cheaper products. Where will these new products come from? How will we find ways to make better products at lower cost? The answer is clear. There must be a stream of new scientific knowledge to turn the wheels of private and public enterprise. There must be plenty of men and women trained in science and technology for upon them depend both the creation of new knowledge and its application to practical purposes. (...)

New products and new processes do not appear full-grown. They are founded on new principles and new conceptions, which in turn are painstakingly developed by research in the purest realms of science.

Today, it is truer than ever that basic research is the pacemaker of technological progress. In the nineteenth century, Yankee mechanical ingenuity, building largely upon the basic discoveries of European scientists, could greatly advance the technical arts. Now the situation is different.

A nation which depends upon others for its new basic scientific knowledge will be slow in its industrial progress and weak in its competitive position in world trade, regardless of its mechanical skill." (Bush, 1945, chapter 3)

By the second half of the 1960 s the so-called market-pull model contested that reasoning, portraying demand as the driving force of innovation. Then a long-lasting and detailed discussion started to establish which of these two types of models is correct, that is, whether R\&D results or market demands are the most important information sources of innovations. ${ }^{7}$

Both the science-push and the market-pull models portray innovation processes as linear ones. (Figure 1)

\footnotetext{
${ }^{6}$ This brief account can only list the most influential models; Balconi et al. (2010); Caraça et al. (2009); Dodgson and Rothwell (1994); and Godin (2006) offer detailed discussions on their emergence, properties and use for analytical and policy-making purposes.

7 It is telling that a recent review of this discussion by Di Stefano et al. (2012) draws on one hundred papers.
} 


\section{Linear models of innovation}

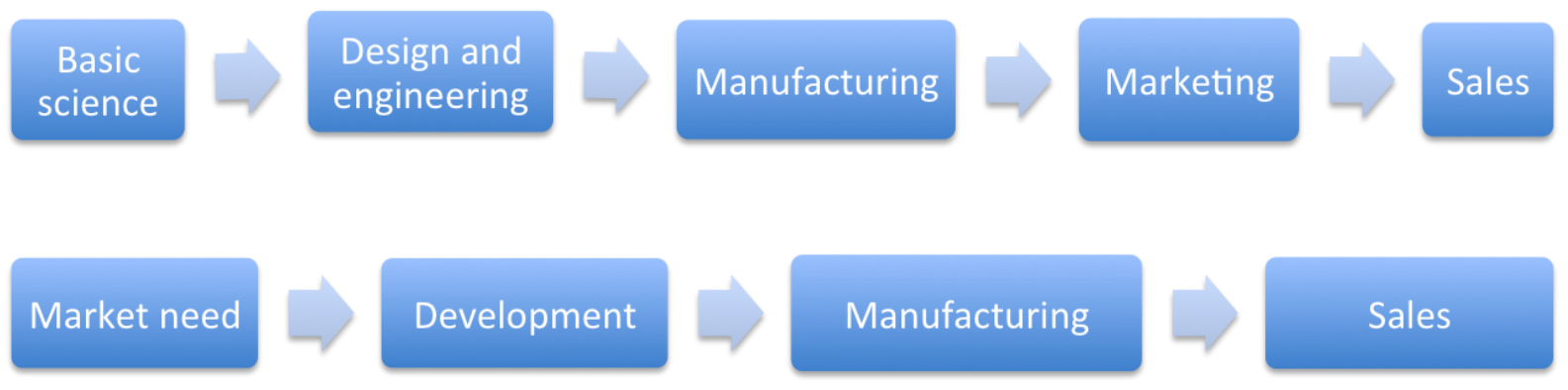

Source: Dodgson and Rothwell (eds) (1994), Figures 4.3 and 4.4 (p. 41)

This common feature has somewhat eclipsed the differences among these models when Kline and Rosenberg (1986) suggested the chain-linked model of innovation, stressing the non-linear property of innovation processes, the variety of sources of information, as well as the importance of various feedback loops. (Figure 2)

Figure 2

\section{The chain-linked model of innovation}

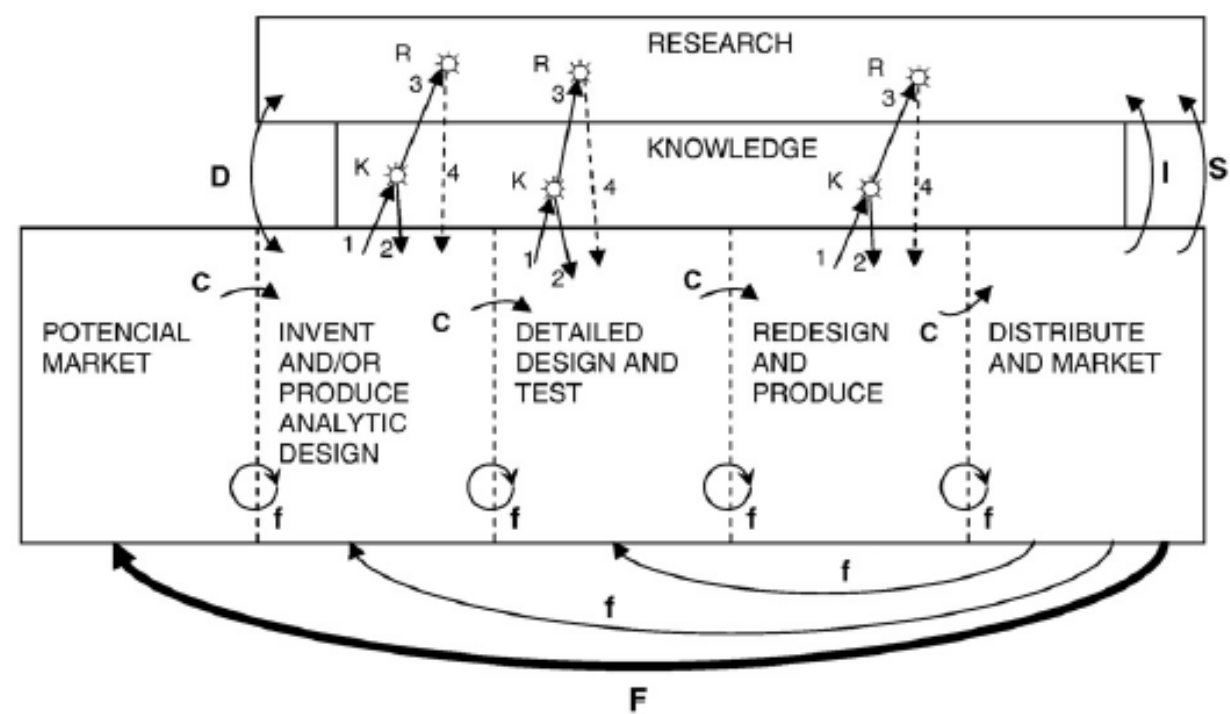

Chain-linked model showing flow paths of information and cooperation.

Symbols on arrows: $\mathbf{C}=$ central-chain-of-innovation; $\mathbf{f}=$ feedback loops; $\mathbf{F}=$ particularly important feedback.

K-R: Links through knowledge to research and return paths. If problems solved at node $\mathrm{K}$, link 3 to $\mathrm{R}$ not activated. Return from research (link 4) is problematic - therefore dashed line.

D: Direct link to and from research from problems in invention and design.

I: Support of scientific research by instruments, machines, tools, and procedures of technology.

S: Support of research in sciences underlying product area to gain information directly and by monitoring outside work. The information obtained may apply anywhere along the chain.

Source: Kline and Rosenberg (1986) 
The chain-link model has then been extended into the networked model of innovation; its recent, highly sophisticated version is called the multi-channel interactive learning model. (Caraça et al., 2009) (Figure 3) This model

"has representational purposes and not representative ones, i.e. it does not assume that all factors have to be in place for innovation to be realised and successful. Rather, it tries to provide a stylised representation of the main classes of variables, and their interrelationships, which are involved in the innovation process taking place in a wide array of industries. (...)

Thus, the model is an analytical grid that describes and contextualises elements, but it also provides a set of flexible generalisations upon which to base our thinking when trying to explain the sources and stages of the innovation process. It points to the ubiquitous experience-based learning processes taking place within firms, as well as at the interfaces with users, suppliers and competitors." (Caraça et al., 2009: 864866; emphasis added -AH; footnotes are removed from the original)

Figure 3

\section{The multi-channel interactive learning model of innovation}

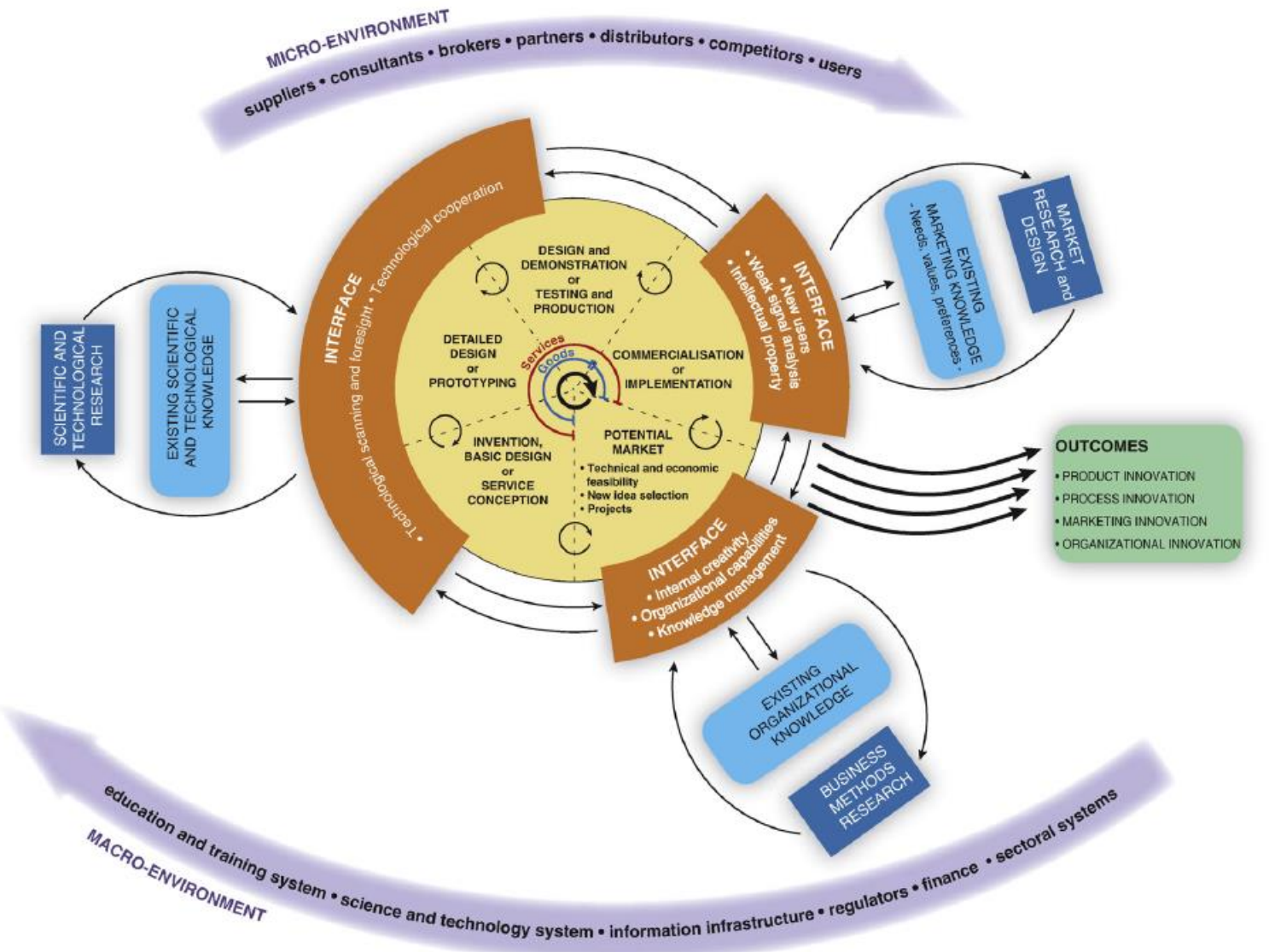

Source: Caraça et al. (2009)

\subsection{INNOVATION IN ECONOMICS PARADIGMS}

Technological, organisational, managerial changes and opening up new markets had been a major theme in classical economics - without using the term innovation. (Havas, 2015b) Then neo-classical economics essentially abandoned research questions concerned with dynamics, and instead focused on static allocative efficiency. Optimisation was the key issue 
for this school, assuming homogenous products, diminishing returns to scale, technologies accessible to all producers at zero cost, perfectly informed economic agents, perfect competition, and thus zero profit. Technological changes were treated as exogenous to the economic system, while other types of innovations were not considered at all. Given the empirical findings and theoretical work on firm behaviour and the operation of markets, mainstream industrial economics and organisational theory has relaxed the most unrealistic assumptions, especially perfect information, deterministic environments, perfect competition, and constant or diminishing returns. Yet, "this literature has not addressed institutional issues, it has a very narrow concept of uncertainty, it has no adequate theory of the creation of technological knowledge and technological interdependence amongst firms, and it has no real analysis of the role of government.” (Smith, 2000: 75)

Evolutionary economics of innovation rests on radically different postulates compared to mainstream economics. ${ }^{8}$ The latter assumes rational agents, who can optimise via calculating risks and taking appropriate actions, while the former stresses that "innovation involves a fundamental element of uncertainty, which is not simply the lack of all the relevant information about the occurrence of known events, but more fundamentally, entails also (a) the existence of techno-economic problems whose solution procedures are unknown, and (b) the impossibility of precisely tracing consequences to actions". (Dosi, 1988a: 222 emphasis added) Thus, optimisation is impossible on theoretical grounds.

Availability of information (symmetry vs. asymmetry among agents in this respect) has been the central issue in mainstream economics until recently. Evolutionary economics, in contrast, has stressed since its beginnings that the success of firms depends on their accumulated knowledge - both codified and tacit -, skills, as well as learning capabilities. Information can be purchased (e.g. as a manual, blueprint, or licence), and hence can be accommodated in mainstream economics as a special good relatively easily and comfortably. Yet, knowledge - and a fortiori, the types of knowledge required for innovation, e.g. tacit knowledge, skills, and competence in pulling together and exploiting available pieces of information - cannot be bought and used instantaneously. A learning process cannot be spared if one is to acquire knowledge and skills, and it is not only time-consuming, but the

\footnotetext{
8 The so-called new or endogenous growth theory is not discussed here separately because its major implicit assumptions on knowledge are very similar to those of mainstream economics. (Lazonick, 2013; Smith, 2000) Moreover, knowledge in new growth models is reduced to codified scientific knowledge, in sharp contrast to the much richer understanding of knowledge in evolutionary economics of innovation. When summarising the "evolution of science policy and innovation studies" (SPIS), Martin (2012: 1230) also considers this school as part of mainstream economics: "Endogenous growth theory is perhaps better seen not so much as a contribution to SPIS but rather as a response by mainstream economists to the challenge posed by evolutionary economics."
} 
costs of trial and error need to be incurred as well. 9 Thus, the uncertain, cumulative and path-dependent nature of innovation is reinforced.

Cumulativeness, path-dependence and learning lead to heterogeneity among firms, as well as other organisations. On top of that, sectors also differ in terms of major properties and patterns of their innovation processes. (Castellacci, 2008b; Malerba, 2002; Pavitt, 1984; Peneder, 2010)

Innovators are not lonely champions of new ideas. While talented individuals may develop radically new, brilliant scientific or technological concepts, successful innovations require various types and forms and knowledge, rarely possessed by a single organisation. A close collaboration among firms, universities, public and private research organisations, and specialised service-providers is, therefore, a prerequisite of major innovations, and can take various forms, from informal communications through highly sophisticated $R \& D$ contracts to alliances and joint ventures. (Freeman, 1991, 1994, 1995; Lundvall and Borrás, 1999; OECD, 2001; Smith, 2000, 2002; Tidd et al., 1997) In other words, 'open innovation' is not a new phenomenon at all. (Mowery, 2009)

\subsection{POLICY RATIONALES DERIVED FROM ECONOMIC THEORIES}

Different policy rationales can be drawn from competing schools of economic thought. Mainstream economics is primarily concerned with market failures: the unpredictability of knowledge outputs from inputs, the inappropriability of full economic benefits of private investment in knowledge creation, and the indivisibility in knowledge production lead to a 'suboptimal' level of business R\&D efforts. Policy interventions, therefore, are justified if they aim at (a) creating incentives to boost private $R \& D$ expenditures by ways of subsidies and protection of intellectual property rights, or (b) funding for public R\&D activities.

Evolutionary economics of innovation investigates the role of knowledge creation and exploitation in economic processes; that is, it does not focus exclusively on R\&D. This school considers various types and forms of knowledge, including practical or experience-based

\footnotetext{
9 Arrow (1962) was already discussing „The Economic Implications of Learning by Doing”, and Rosenberg (1982) stressed the importance of learning by using (ch. 6). Recently, learning has become a more regular subject in mainstream economics, most notably in game theory. For instance, while „learning” only appeared twice in the title of NBER working papers in 1996, it occurred 5 times in 1999, 6 times in 2002, 13 times in 2008, 10 times in 2013, and 12 times in 2014, among others in the forms of „learning by doing”, „learning from experience”, and „learning from exporting” - but also „learning from state longitudinal data systems” and „learning millennialstyle". (It should be added that at least 15-20 NBER working papers are published a week.) Taking the titles and abstracts of articles published in the American Economic Review, „learning” occurred first in 1999, then 2-3 times a year in 2002-2006; 4 times in 2008, 2011, and 2012; 5 times in 2013; 6 times in 2007, 2010, and 2014; and 7 times in 2009. These articles discuss a wide variety of research themes - e.g. behaviour of firms and other organisations, business cycles, stock exchange transactions, forecasting of economic growth, mortgage, art auctions, game theory, behavioural economics, energy, health, labour market - and modes of learning. Thus, not all these articles are relevant from the point of analysing innovation processes (e.g. „learning [one's] HIV status” is not part of an innovation process). Further, in several cases knowledge is narrowed down to patents, which is clearly a misconception. Yet, a detailed analysis of the substance of these articles is beyond the scope of this paper.
} 
knowledge acquired via learning by doing, using and interacting. As these are all relevant to innovation, scientific knowledge is far from being the only type of knowledge required for a successful introduction of new products, processes or services, let alone non-technological innovations. R\&D is undoubtedly among the vital sources of knowledge. Besides in-house R\&D projects, however, results of other $R \& D$ projects are also widely utilised during the innovation process: extramural projects conducted in the same or other sectors, at public or private research establishments, home or abroad. More importantly, there are a number of other sources of knowledge, also essential for innovations, such as design, scaling up, testing, tooling-up, trouble-shooting, and other engineering activities, ideas from suppliers and users, inventors' concepts and practical experiments (Hirsch-Kreinsen et al. (eds), 2005; Klevorick et al., 1995; Lundvall (ed.), 1992; Lundvall and Borrás, 1999; Rosenberg, 1996, 1998; von Hippel, 1988), as well as collaboration among engineers, designers, artists, and other creative 'geeks'. Further, innovative firms also utilise knowledge embodied in advanced materials and other inputs, equipment, and software.

The Community Innovation Survey (CIS) defines its own set of categories as highly important sources of information for product and process innovation: the enterprise or the enterprise group; suppliers of equipment, materials, components or software; clients or customers; competitors or other enterprises from the same sector; consultants, commercial labs or private $\mathrm{R} \& \mathrm{D}$ institutes; universities or other higher education institutes; government or public research institutes; conferences, trade fairs, exhibitions; scientific journals and trade/ technical publications; and professional and industry associations. All rounds of CIS clearly and consistently show that firms regard a wide variety of sources of information as highly important ones for innovation, but given space limits, only the 2010-2012 data are reported in Figures $4-5 \cdot{ }^{10}$

\footnotetext{
${ }^{10}$ Data for the 2006-2008 and 2008-2010 periods are presented in Appendix 1.
} 
Highly important 'business' sources of information for product and process innovation, EU members, 2010-2012

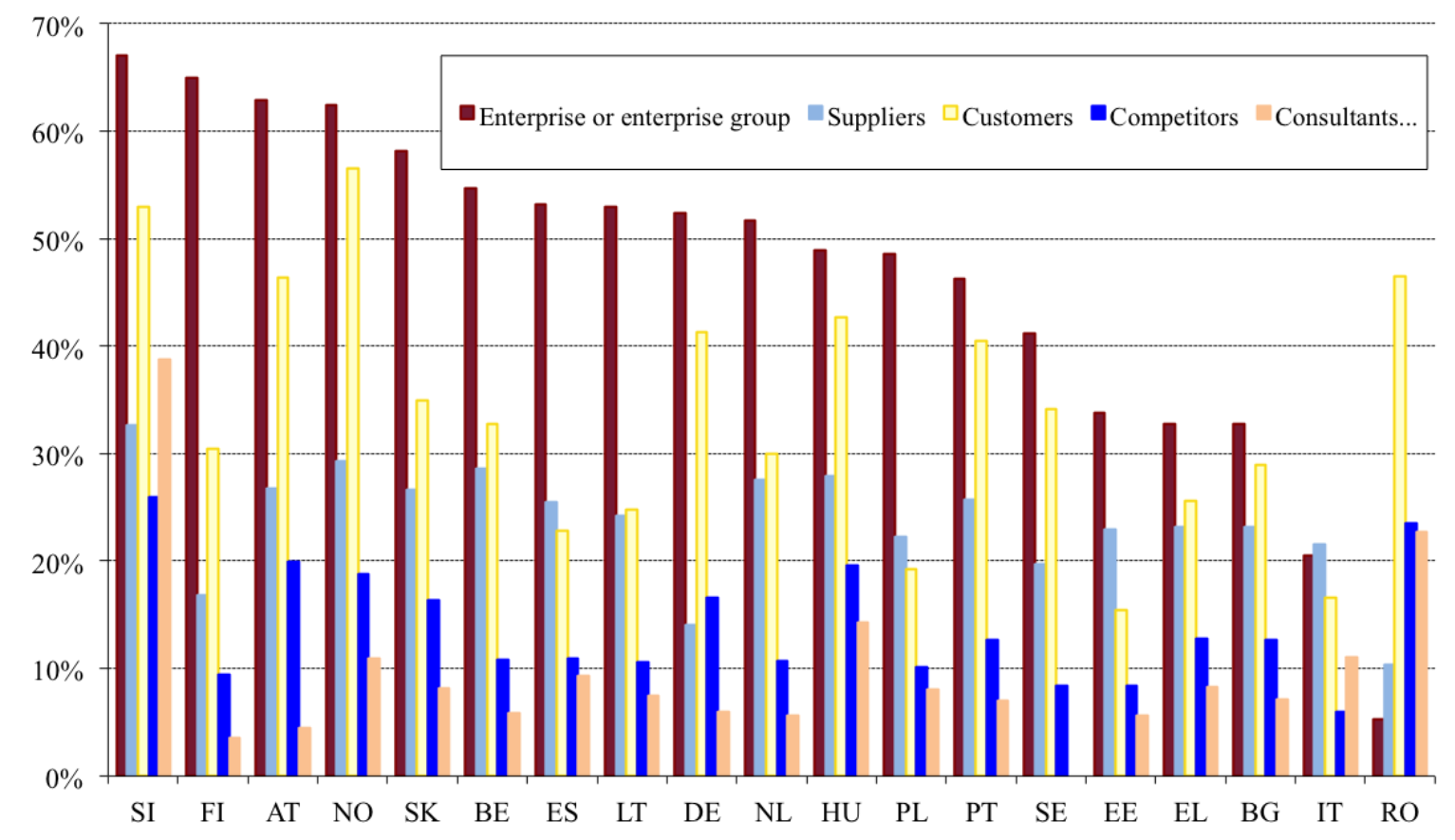

Source: Eurostat, CIS2012

Note: Data for Cyprus, Luxembourg and Malta are not included in this figure.

Figure 5

Highly important 'scientific' sources of information for product and process innovation, EU members, 2010-2012

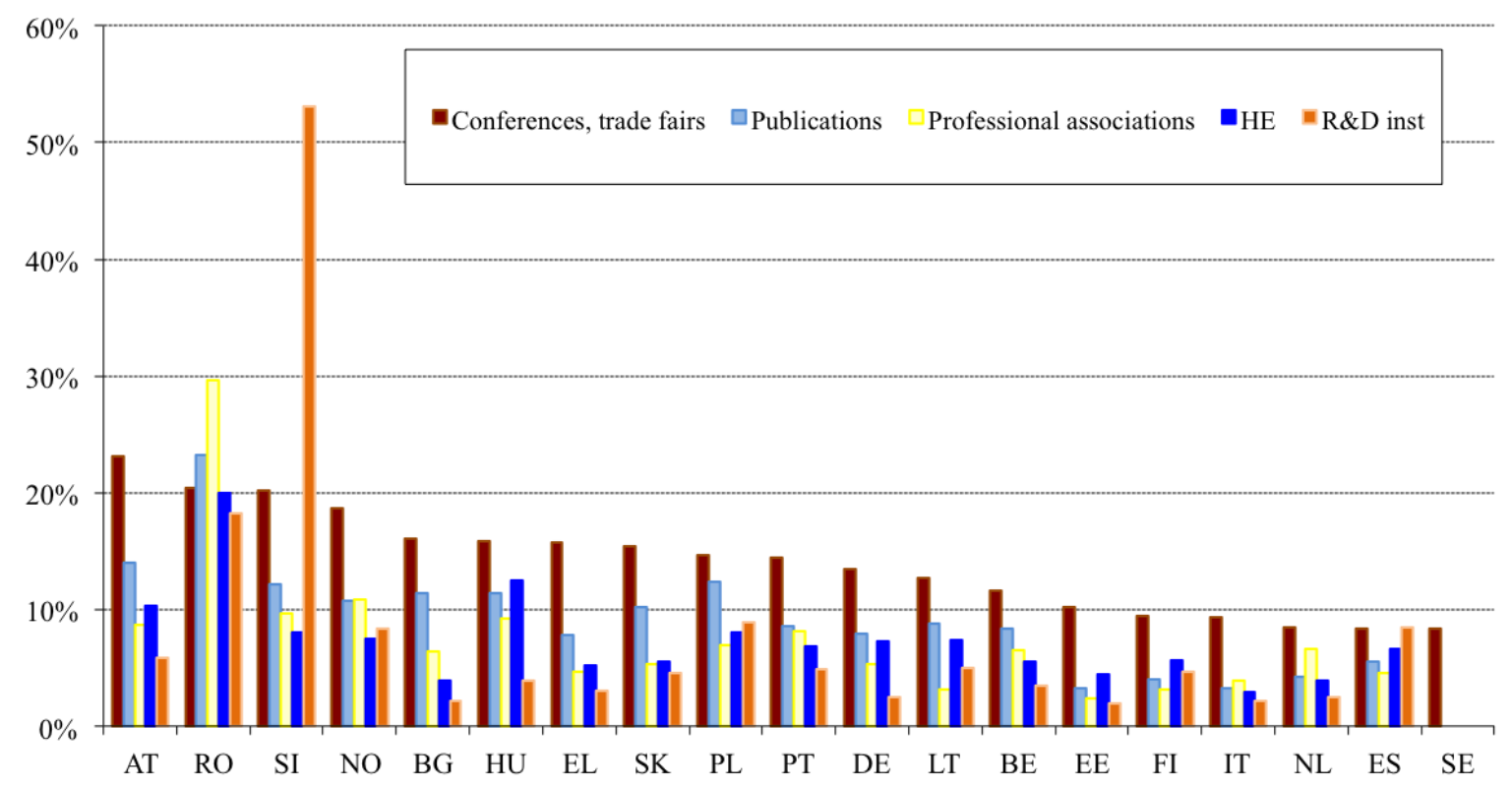

Source: Eurostat, CIS2012

Note: Data for Cyprus, Luxembourg and Malta are not included in this figure. 
The wide variety of knowledge drawn on in innovation processes is a crucial point to bear in mind as the OECD classification of industries only takes into account expenditures on formal R\&D activities, carried out within the boundaries of a given sector. ${ }^{11}$ In other words, a number of highly successful, innovative firms, exploiting advanced knowledge created externally in distributed knowledge bases (Smith, 2002) and internally by non-R\&D processes, are classified as medium-low-tech or low-tech, just because their $\mathrm{R} \& \mathrm{D}$ expenditures are below the threshold set by the OECD.

In sum, evolutionary economics of innovation posits that the success of firms is largely determined by their abilities to exploit various types of knowledge, generated by both R\&D and non-R\&D activities. Knowledge generation and exploitation takes place in, and is fostered by, various forms of internal and external interactions. The quality and frequency of the latter is largely determined by the properties of a given innovation system, in which these interactions take place. STI policies, therefore, should aim at strengthening the respective innovation system and improving its performance by tackling systemic failures hampering the generation, diffusion and utilisation of any type of knowledge required for successful innovation. ${ }^{12}$ (Edquist, 2011; Foray (ed.), 2009; Freeman, 1994; Lundvall and Borrás, 1999; OECD, 1998; Smith, 2000) From a different angle, conscious, co-ordinated policy efforts are needed to promote knowledge-intensive activities in all sectors.

\section{THE INNOVATION UNION SCOREBOARD}

As shown above, firms exploit various types of knowledge for their innovation activities. Applying this general observation to the Danish case, and relying on the DISKO survey, Jensen et al. (2007) made an elementary distinction between two modes of innovation: (a) one based on the production and use of codified scientific and technical knowledge (in brief, the ST mode), and (b) another one relying on informal processes of learning and experiencebased know-how (called DUI: learning by Doing, Using and Interacting).

Following this distinction, the indicators used in the various editions of the Innovation Union Scoreboard ${ }^{13}$ are characterised below, using a rudimentary classification. An indicator can be relevant to reflect:

\footnotetext{
${ }_{11}$ The so-called indirect R\&D intensity has been also calculated as R\&D expenditures embodied in intermediates and capital goods purchased on the domestic market or imported. Yet, it has been concluded that indirect R\&D intensities would not influence the classification of sectors. (Hatzichronoglou, 1997: 5)

${ }^{12}$ In an attempt to systematically compare the market and systemic failure policy rationales, Bleda and del Río (2013) introduce the notion of evolutionary market failures, and reinterpret „the neoclassic market failures” as particular cases of evolutionary market failures, relying on the crucial distinction between knowledge and information.

13 The Innovation Union Scoreboard originally was called European Innovation Scoreboard (EIS). The EIS and IUS indicators have been revised several times since the first edition of the scoreboard, that is, EIS 2002. The current name of the scoreboard was introduced in 2010.
} 
- only R\&D-based innovations

- mainly R\&D-based innovations

- only non-R\&D-based innovations

- mainly non-R\&D-based innovations

- both types of innovations.

This rudimentary classification reveals a bias towards R\&D-based innovations in the first edition of the EIS: 10 indicators were only relevant for R\&D-based innovations; 8 could be relevant for both types of innovations; and none focused on non-R\&D-based innovations. ${ }^{14}$ (Table 1)

14 A fairly detailed, partly technical, partly substantive discussion would be needed to refine this simple classification. 
The 2002 European Innovation Scoreboard indicators

\begin{tabular}{|c|c|c|}
\hline & $\begin{array}{c}\text { Relevance } \\
\text { for R\&D- } \\
\text { based } \\
\text { innovation }\end{array}$ & $\begin{array}{c}\text { Relevance } \\
\text { for non- } \\
\text { R\&D- } \\
\text { based } \\
\text { innovation } \\
\end{array}$ \\
\hline \multicolumn{3}{|l|}{1 Human resources } \\
\hline $\begin{array}{l}\text { New S\&E graduates (ISCED 5a and above) per } 1000 \text { population aged } \\
20-29\end{array}$ & $\mathrm{X}$ & \\
\hline Population with tertiary education (\% of $25-64$ years age class) & $\mathrm{b}$ & $\mathrm{b}$ \\
\hline Participation in life-long learning (\% of $25-64$ years age class) & $\mathrm{b}$ & $\mathrm{b}$ \\
\hline $\begin{array}{l}\text { Employment in medium-high and high-tech manufacturing (\% of } \\
\text { total workforce) }\end{array}$ & $\mathrm{X}$ & \\
\hline $\begin{array}{l}\text { Employment in high-tech services (\% of total workforce) } \\
2 \text { Knowledge creation }\end{array}$ & $\mathrm{X}$ & \\
\hline Public R\&D expenditures (GERD - BERD) (\% of GDP) & $\mathrm{X}$ & \\
\hline Business expenditures on R\&D (BERD) (\% of GDP) & $\mathrm{X}$ & \\
\hline EPO high-tech patent applications (per million population) & $\mathrm{X}$ & \\
\hline USPTO high-tech patent applications (per million population) & $\mathrm{X}$ & \\
\hline 3 Transmission and application of knowledge & & \\
\hline SMEs innovating in-house (\% of manufacturing SMEs) & $\mathrm{b}$ & $\mathrm{b}$ \\
\hline $\begin{array}{l}\text { SMEs involved in innovation co-operation (\% of manufacturing } \\
\text { SMEs) }\end{array}$ & $\mathrm{b}$ & $\mathrm{b}$ \\
\hline $\begin{array}{l}\text { Innovation expenditures (\% of all turnover in manufacturing) } \\
4 \text { Innovation finance, output and markets }\end{array}$ & $\mathrm{b}$ & $\mathrm{b}$ \\
\hline High technology venture capital investment (\% of GDP) & $\mathrm{X}$ & \\
\hline $\begin{array}{l}\text { Capital raised on parallel markets plus by new firms on main markets } \\
(\% \text { of GDP })^{\mathrm{i}}\end{array}$ & $\mathrm{X}$ & \\
\hline $\begin{array}{l}\text { Sales of 'new to market' products (\% of all turnover in } \\
\text { manufacturing) }\end{array}$ & $\mathrm{b}$ & $\mathrm{b}$ \\
\hline Home internet access (\% of all households) & $\mathrm{b}$ & $\mathrm{b}$ \\
\hline ICT expenditures (\% of GDP) & $\mathrm{b}$ & $\mathrm{b}$ \\
\hline Share of manufacturing value-added in high-tech & $\mathrm{X}$ & \\
\hline \multicolumn{3}{|c|}{$\begin{array}{l}\text { Legend: } \\
\text { X: only relevant } \\
\text { x: mainly relevant } \\
\text { b: relevant for both types } \\
\text { Source: own compilation, drawing on the detailed definition of indicators, EC (2002). } \\
\text { Notes: Public R\&D expenditures do not equal to GERD - BERD; rather, it should be the sum of government- } \\
\text { funded parts of BERD, GOVERD, and HERD } \\
\text { Three indicators, namely EPO patent applications (per million population), Home internet access (per } 100 \\
\text { population), and Inward FDI stock (\% of GDP) were only used for candidate countries. } \\
\text { i "Parallel stock exchanges focus on high technology sectors." (EC, 2002: 31) }\end{array}$} \\
\hline
\end{tabular}

The 2014 and 2015 editions of the IUS use 25 indicators, grouped by 8 innovation dimensions. (EC, 2014, 2015) Repeating the same exercise shows that the bias towards R\&Dbased innovations has been kept: 10 of the most recent IUS indicators ${ }^{15}$ are only relevant for, and a further four mainly capture, R\&D-based innovations; seven could be relevant for both types of innovations; and a mere four focus on non-R\&D-based innovations. (Table 2)

15 There was only a slight change introduced in 2015: the indicator called "Contribution of medium and high-tech product exports to the trade balance" was replaced by "Exports of medium and high-technology products as a share of total product exports". This change had no effect on the nature of the indicators, and thus the 2014 edition of the IUS is not presented here. 
The 2015 Innovation Union Scoreboard indicators

\begin{tabular}{|c|c|c|}
\hline & $\begin{array}{c}\text { Relevance } \\
\text { for R\&D- } \\
\text { based } \\
\text { innovation }\end{array}$ & $\begin{array}{c}\text { Relevance } \\
\text { for non- } \\
\text { R\&D- } \\
\text { based } \\
\text { innovation }\end{array}$ \\
\hline \multicolumn{3}{|l|}{ Human resources } \\
\hline New doctorate graduates (ISCED 6) per 1000 population aged 25-34 & $\mathrm{X}$ & \\
\hline $\begin{array}{l}\text { Percentage population aged 30-34 having completed tertiary } \\
\text { education }\end{array}$ & $\mathrm{b}$ & $\mathrm{b}$ \\
\hline $\begin{array}{l}\text { Percentage youth aged } 20-24 \text { having attained at least upper } \\
\text { secondary level education }\end{array}$ & $\mathrm{b}$ & $\mathrm{b}$ \\
\hline \multicolumn{3}{|l|}{ Open, excellent and attractive research systems } \\
\hline International scientific co-publications per million population & $\mathrm{X}$ & \\
\hline $\begin{array}{l}\text { Scientific publications among the top } 10 \% \text { most cited publications } \\
\text { worldwide as \% of total scientific publications of the country }\end{array}$ & $\mathrm{X}$ & \\
\hline $\begin{array}{l}\text { Non-EU doctorate studentsi as a \% of all doctorate students } \\
\text { Finance and support }\end{array}$ & $\mathrm{X}$ & \\
\hline R\&D expenditure in the public sector as \% of GDP & $\mathrm{X}$ & \\
\hline Venture capital investment as \% of GDP & $\mathrm{x}$ & \\
\hline \multicolumn{3}{|l|}{ Firm investments } \\
\hline R\&D expenditure in the business sector as \% of GDP & $\mathrm{X}$ & \\
\hline $\begin{array}{l}\text { Non-R\&D innovation expenditures as \% of turnover } \\
\text { Linkages \& entrepreneurship }\end{array}$ & & $\mathrm{X}$ \\
\hline SMEs innovating in-house as \% of SMEs & $\mathrm{b}$ & $\mathrm{b}$ \\
\hline Innovative SMEs collaborating with others as \% of SMEs & $\mathrm{b}$ & $\mathrm{b}$ \\
\hline Public-private co-publications per million population & $\mathrm{X}$ & \\
\hline \multicolumn{3}{|l|}{ Intellectual assets } \\
\hline PCT patents applications per billion GDP (in PPS€) & $\mathrm{X}$ & \\
\hline $\begin{array}{l}\text { PCT patent applications in societal challenges per billion GDP (in } \\
\text { PPS€) (environment-related technologies; health) }\end{array}$ & $\mathrm{X}$ & \\
\hline Community trademarks per billion GDP (in PPS€) & & $\mathrm{X}$ \\
\hline Community designs per billion GDP (in PPS€) & & $\mathrm{X}$ \\
\hline \multicolumn{3}{|l|}{ Innovators } \\
\hline SMEs introducing product or process innovations as \% of SMEs & $\mathrm{b}$ & $\mathrm{b}$ \\
\hline $\begin{array}{l}\text { SMEs introducing marketing or organisational innovations as \% of } \\
\text { SMEs }\end{array}$ & & $\mathrm{X}$ \\
\hline \multicolumn{3}{|l|}{ Economic effects } \\
\hline $\begin{array}{l}\text { Employment in fast-growing enterprises in innovative sectors (\% of } \\
\text { total employment) }\end{array}$ & $\mathrm{b}$ & $\mathrm{b}$ \\
\hline $\begin{array}{l}\text { Employment in knowledge-intensive activities (manufacturing and } \\
\text { services) as \% of total employment }\end{array}$ & $\mathrm{x}$ & \\
\hline $\begin{array}{l}\text { Exports of medium and high-technology products as a share of total } \\
\text { product exports }\end{array}$ & $\mathrm{x}$ & \\
\hline Knowledge-intensive services exports as \% total service exports & $\mathrm{x}$ & \\
\hline Sales of new to market and new to firm innovations as \% of turnover & $\mathrm{b}$ & $\mathrm{b}$ \\
\hline License and patent revenues from abroad as \% of GDP & $\mathrm{X}$ & \\
\hline
\end{tabular}

Legend:

$\mathrm{X}$ : only relevant

$\mathrm{x}$ : mainly relevant

b: relevant for both types

Source: own compilation

${ }^{\mathrm{i}}$ It is a somewhat strict definition of openness, which only takes into account non-EU doctorate students. 
Again, a fairly detailed, partly technical, partly substantive discussion would be needed to refine this simple classification, especially concerning the following issues: to what extent upper secondary education, venture capital, employment in knowledge-intensive activities, and knowledge-intensive services exports are relevant indicators to capture non-R\&D-based innovations; and to what extent non-R\&D-based innovation activities are needed for successful R\&D-based innovations?

The indicators used in the previous editions of the EIS and IUS are characterised in Appendix 2 (Tables A1-A7). To give an overview of the evolution of the EIS and IUS indicators, results are summarised in Table 3. In sum, the bias towards R\&D-based innovations has been rather persistent, although there has been some fluctuation.

Several conclusions can be drawn from the above considerations for analysing social innovation.

First, while the number and definitions of indicators used to compile the various editions of EIS and IUS have changed to a non-negligible extent since 2002, these indicators consistently focus on measuring $\mathrm{R} \& \mathrm{D}$ activities (inputs and outputs) and R\&D-based innovation activities. In other words, they can be relevant in settings characterised predominantly by the so-called ST mode of innovation, but significantly less so in other settings, characterised by other types of innovation activities. In other words, using the EIS or IUS indicators would not help establishing if a certain system is characterised by a low level of innovation activities altogether - or a low level of R\&D-based innovation activities. Yet, that is a fairly important distinction both from an analytical and a practical (policy) point of view: these two systems (settings) are fundamentally different.

Several analysts and policy-makers tend to believe that advanced economies can be sufficiently characterised by focussing on the ST mode of innovation, on the one hand, and less advanced economies should also attempt to change the sectoral composition of their economy by increasing the weight of the so-called high-tech (HT) sectors, on the other. These views, however, cannot be corroborated by empirical evidence. 
The evolution of the EIS and IUS indicators, 2002-2014

\begin{tabular}{|c|c|c|c|c|c|c|c|c|c|}
\hline & EIS 2002 & EIS 2003 & EIS 2004 & $\begin{array}{l}\text { EIS } 2005 \\
\text { EIS } 2006\end{array}$ & EIS 2007 & EIS 2008 & EIS 2009 & $\begin{array}{r}\text { IUS } 2010 \\
- \text { IUS } 2013\end{array}$ & $\begin{array}{l}\text { IUS } 2014 \\
\text { IUS } 2015\end{array}$ \\
\hline \multicolumn{10}{|l|}{ Indicators reflecting } \\
\hline only R\&D-based innovations & 10 & 9 & 9 & 8 & 7 & 8 & 8 & 10 & 10 \\
\hline mainly R\&D-based innovations & - & 3 & 3 & 5 & 5 & 4 & 4 & 4 & 4 \\
\hline both types & 8 & 9 & 9 & 12 & 12 & 15 & 16 & 6 & 7 \\
\hline only non-R\&D-based innovations & - & - & - & - & - & 1 & 1 & 4 & 4 \\
\hline mainly non-R\&D-based innovations & - & - & 1 & 1 & 1 & 1 & 1 & - & - \\
\hline Number of indicators & 18 & 21 & 22 & 26 & 25 & 29 & 30 & 24 & 25 \\
\hline
\end{tabular}


Any simple statistical analysis reveals that the so-called high-tech sectors - supposed to be drivers of economic development, due to their intense ST mode innovation activities have a fairly low weight either in output or employment. Innovation studies have shown that technological innovations can hardly be introduced without organisational and managerial innovations. Moreover, the latter ones - together with marketing innovations - are vital for the success of the former ones. ${ }^{16}$ (Pavitt, 1999; Tidd et al., 1997) Further, those companies are the most successful ones, which consciously combine the ST and DUI modes of innovation. (Jensen et al., 2007)

Yet, the high-tech myth is so powerful that even those researchers who base their work on thorough analysis of facts are taken by surprise when the facts are at odds with the widespread obsession with high-tech. A telling example is Peneder's excellent study on the 'Austrian paradox':

"On the one hand, macroeconomic indicators on productivity, growth, employment and foreign direct investment indicate that overall performance is stable and highly competitive. On the other hand, an international comparison of industrial structures reveals a severe gap in the most technologically advanced branches of manufacturing, suggesting that Austria is having problems establishing a foothold in the dynamic markets of the future." (Peneder, 1999: 239)

In contrast, evolutionary economics of innovation claims that any firm - belonging to either a low- and medium-technology (LMT) or a HT sector - can become competitive in 'the dynamic markets of the future' if it is successful in combining its own, firm-specific innovative capabilities with 'extra-mural' knowledge available in distributed knowledge bases. In other words, Austrian policy-makers need not be concerned with the observed 'paradox' as long as they help Austrian firms sustain their learning capabilities, and maintain thereby their innovativeness. That would lead to good economic performance - irrespective of the share of LMT industries in the economy.

From a different angle, while the bulk of innovation activities in the LMT sectors are not based on intramural R\&D efforts, these sectors also improve their performance by various types of innovations. These firms are usually engaged in the DUI mode of innovation, but they also draw on advanced S\&T results available through the so-called distributed knowledge bases (Robertson and Smith, 2008; Smith, 2002), as well as advanced materials, production equipment, software and various other inputs (e.g. electronics components and sub-systems) supplied by HT industries. (Bender et al. (eds), 2005; Hirsch-Kreinsen et al. (eds), 2005; Hirsch-Kreinsen and Jacobson (eds), 2008; Hirsch-Kreinsen and Schwinge (eds) 2014; Jensen et al., 2007; Kaloudis et al., 2005; Mendonça, 2009; Sandven et al.,

\footnotetext{
${ }^{16}$ Although it goes without saying that not all technological innovations are based on R\&D results, people tend to forget this basic fact. Certain organisational, managerial, marketing and financial innovations, in turn, draw on R\&D results (but usually not stemming from R\&D activities conducted or financed by firms). For these two reasons it would be a mistake to equate technological innovations with R\&D-based innovations.
} 
2005; von Tunzelmann and Acha, 2005) Thus, demand by the LMT sectors constitutes major market opportunities for HT firms, and also provides strong incentives - and ideas for their RTDI activities. (Robertson et al., 2009)

It is worth recalling that the 2003 EIS report also stressed the importance of the LMT sectors, as well as the significance of their innovation activities:

„The EIS has been designed with a strong focus on innovation in high-tech sectors. Although these sectors are very important engines of technological innovation, they are only a relatively small part of the economy as measured in their contribution to GDP and total employment. The larger share of low and medium-tech sectors in the economy and the fact that these sectors are important users of new technologies merits a closer look at their innovation performance. This could help national policy makers with focusing their innovation strategies on existing strength and overcome areas of weakness." (EC, 2003a: 2O)

Since then, however, these ideas have been given less prominence. No doubt, it would be an interesting research question why this is the case, but this paper cannot address this issue. More recently, another EC document, namely the 2013 EU Competitiveness Report is sending 'mixed' messages on these issues. At certain points it reinforces these adverse effects:

„the EU has comparative advantages in most manufacturing sectors (15 out of 23) accounting for about three quarters of EU manufacturing output. (...) Of the 15 sectors with comparative advantages mentioned above, about two-thirds are in the low-tech and medium-low tech manufacturing groups. On a positive note though, even in those sectors EU competitiveness is based on high-end innovative products." (EC, 2013d: 3-4, emphasis added - AH)

Is it a negative phenomenon, then, that around 10 EU LMT sectors are internationally competitive?!? A more balanced view is also offered:

"... the policy priority attached to key enabling technologies which lead to new materials and products in all manufacturing sectors has a strong potential to upgrade EU competitiveness not only in the high-tech sectors but also in the traditional industries." (ibid: 5)

To sum up the first conclusion, analysts and policy-makers dealing with innovation should pay attention to both R\&D-based and non-R\&D-based innovations.

The second conclusion: while social innovations can indeed utilise R\&D-based technological innovations, their essence tends to be organisational, managerial and behavioural changes. The EIS and IUS indicators, in turn, do not capture these types of changes.

\section{THE GLOBAL INNOVATION INDEX}

The Global Innovation Index (GII) has a significantly broader coverage - compared to the IUS - in two respects: it covers well over 100 countries, and considers 81 indicators, 
arranged in 7 "pillars". The seven pillars used in the 2014 edition of the GII include: Institutions (9 indicators), Human capital and research (11), Infrastructure (10), Market sophistication (10), Business sophistication (14), Knowledge and technology outputs (14), and Creative outputs (13). The themes considered by each pillar are summarised in Figure 6.

Figure 6

\section{Framework of the Global Innovation Index 2014}

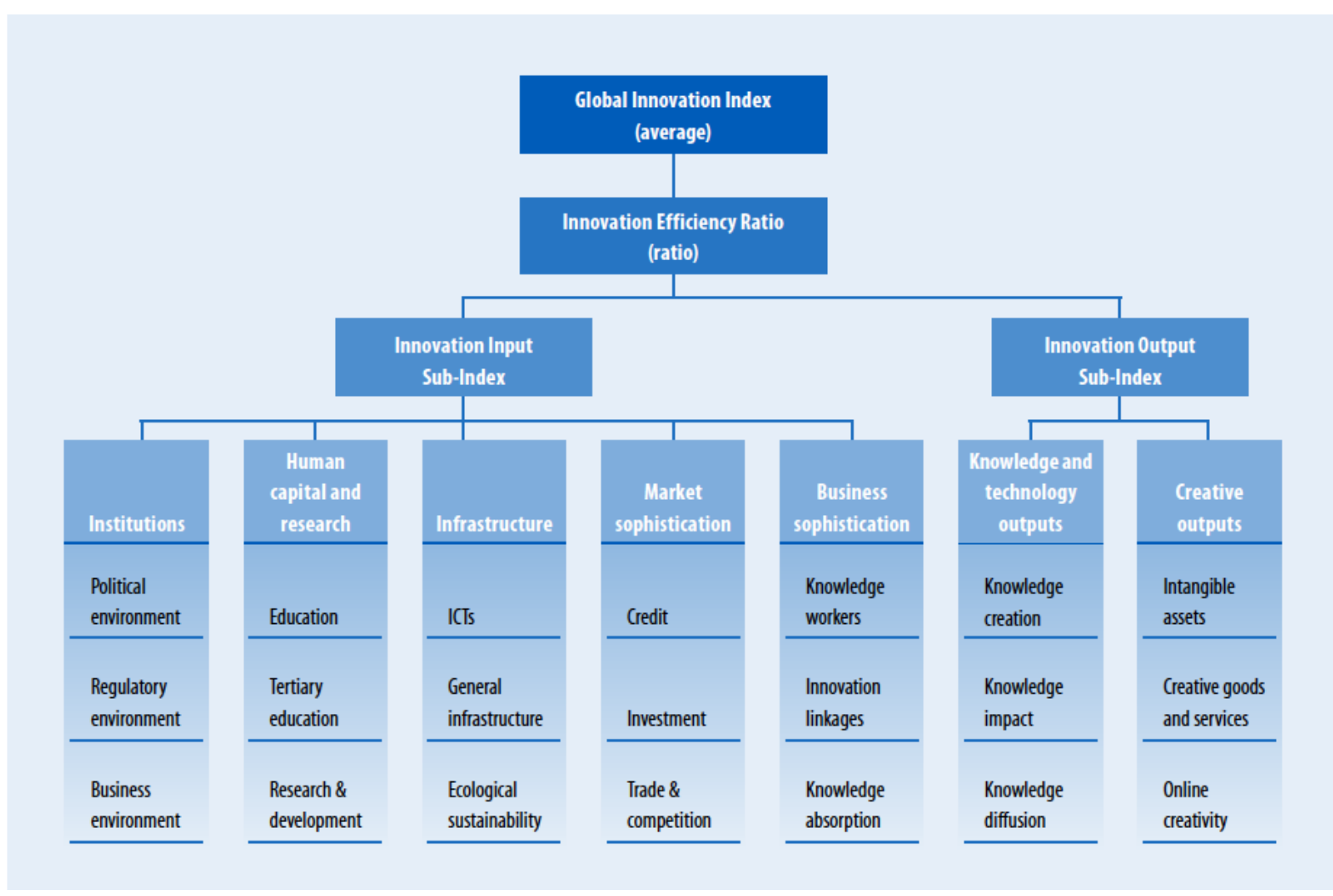

Source: Global Innovation Index 2014

To assess the relevance of these 81 indicators, and especially the 'match' between the themes (or headings) captured by the 7 pillars would require a fairly lengthy paper. In other words, the GII indicators are characterised in a somewhat simplified way here. It should be stressed that most elements are indices themselves, that is, not 'stand-alone' indicators. In other words, several methodological weaknesses are likely to remain hidden.

\section{Pillar 1: Institutions}

Pillar 1 is composed of 3 sub-pillars. The political environment sub-pillar incorporates three indices with the intention to reflect the following aspects: "perceptions of the likelihood that a government might be destabilized; the quality of public and civil services, policy formulation, and implementation; and perceptions of violations to press freedom".

The second sub-pillar, called regulatory environment, is comprised of two indices to capture "perceptions on the ability of the government to formulate and implement cohesive 
policies that promote the development of the private sector and at evaluating the extent to which the rule of law prevails (in aspects such as contract enforcement, property rights, the police, and the courts)". A third indicator is meant to evaluate "the cost of redundancy dismissal as the sum, in salary weeks, of the cost of advance notice requirements added to severance payments due when terminating a redundant worker".

The third sub-pillar, that is, the business environment one is aimed at summarising three aspects directly affecting private entrepreneurial endeavours. It uses the World Bank indices "on the ease of starting a business; the ease of resolving insolvency (based on the recovery rate recorded as the cents on the dollar recouped by creditors through reorganization, liquidation, or debt enforcement/foreclosure proceedings); and the ease of paying taxes". (Cornell University et al., 2014: 45-46)

Not all the above elements are institutions ("rules of the game"), and not all are directly related to innovation processes and performance. It can be argued, though, that the aspects (attempted to be) captured by these indices are relevant to characterise the political, regulatory and business environment for innovation. Among the important missing elements, one should mention legislation on competition, ${ }^{17}$ as well as the entrepreneurial culture in a given country.

\section{Pillar 2: Human capital and research}

Pillar 2 is also comprised of 3 sub-pillars. Sub-pillar 2.1 is composed of several of indicators with the intention to capture achievements at the first two levels of education, namely elementary and secondary education. Education expenditure and school life expectancy are taken as "good proxies for coverage". Government expenditure per pupil at secondary level is meant to indicate "the level of priority given to secondary education by the state". The quality of education is measured via (a) PISA (OECD Programme for International Student Assessment) results indicating 15-year-old students' performances in reading, mathematics, and science, as well as (b) the pupil-teacher ratio.

Sub-pillar 2.2 on tertiary education is designed to measure coverage at this level of education. “(...) priority is given to the sectors traditionally associated with innovation (with a series on the percentage of tertiary graduates in science and engineering, manufacturing, and construction); and the inbound mobility of tertiary students, which plays a crucial role in the exchange of ideas and skills necessary for innovation."

Sub-pillar 2.3 on R\&D is meant to capture the level and quality of R\&D activities by using the number of researchers (headcounts, per million of population), gross expenditures on

\footnotetext{
17 The intensity of comepetition is included in Pillar 4.
} 
R\&D as percentage of GDP, and the quality of scientific and research organisations proxied by the average score of the top three universities in the QS World University Ranking as of 2013. “(...) this indicator aims at capturing the availability of at least three higher education institutions of quality within each economy (i.e., included in the global top 700), and is not aimed at assessing the average level of all institutions within a particular economy." (Cornell University et al., 2014: 46-47)

Formal education is a crucial factor determining the quality of human capital, no doubt, but life-long learning and other, informal modes of learning are also important. Research is conducted outside universities, too, both by other publicly financed research organisations and businesses. Moreover, the quality of research conducted by these latter types of organisations is not necessarily lower than that at universities. Moreover, university rankings themselves suffer from several major methodological weaknesses. Thus, the name of this pillar is more 'ambitious' than its actual content.

\section{Pillar 3: Infrastructure}

The third pillar on infrastructure is also built by three sub-pillars: information and communication technologies (ICT), general infrastructure, and ecological sustainability. Sub-pillar 3.1 on ICT is computed by using four indices developed by international organisations on ICT access, ICT use, on-line service by governments, and on-line participation of citizens. Sub-pillar 3.2 on general infrastructure is composed of "the average of electricity output in kWh per capita; a composite indicator on logistics performance; and gross capital formation, which consists of outlays on additions to the fixed assets and net inventories of the economy, including land improvements (fences, ditches, drains); plant, machinery, and equipment purchases; and the construction of roads, railways, and the like, including schools, offices, hospitals, private residential dwellings, and commercial and industrial buildings". Sub-pillar 3.3 on ecological sustainability is constructed by using three indicators: "GDP per unit of energy use (a measure of efficiency in the use of energy), the Environmental Performance Index of Yale and Columbia Universities, and the number of certificates of conformity with standard ISO 14001 on environmental management systems issued”. (Cornell University et al., 2014: 47)

Ecological sustainability is certainly an important issue, but it is difficult to grasp why it is part of the "Infrastructure" pillar, especially when it is measured by the above three components. These are more relevant to reflect those environmental challenges that are to be addressed by innovation efforts - or the outcome of previous eco-innovation efforts. In other words, there is a certain mismatch between the name of this pillar and its actual content. 


\section{Pillar 4: Market sophistication}

The fourth pillar on market sophistication integrates three sub-pillars "structured around market conditions and the total level of transactions". Sub-pillar 4.1 on credit intends to reflect "the ease of getting credit aimed at measuring the degree to which collateral and bankruptcy laws facilitate lending by protecting the rights of borrowers and lenders, as well as the rules and practices affecting the coverage, scope, and accessibility of credit information". Transactions are measured by the total value of domestic credit to the private sector (as a percentage of GDP) as well as by the gross loan portfolio of microfinance institutions (as a percentage of GDP) with the intention to make the method applicable to emerging markets, too.

Sub-pillar 4.2 on investment is composed of the ease of protecting investors index and three indicators on the level of transactions. Besides stock market capitalisation, the total value of shares traded (as percentage of GDP) is also taken into account to show if market size is matched by market dynamism. Data on venture capital deals (a total of 18,860 deals in 71 countries in 2013) are also exploited.

Sub-pillar 4.3 considers trade and competition. The market conditions for trade are measured by two indicators: the average tariff rate weighted by import shares and a metric on non-agricultural market access conditions to foreign markets (five major export markets weighted actual applied tariffs for non-agricultural exports). The last indicator is a result from a survey: the intensity of competition in local markets. "Efforts made at finding hard data on competition have so far proved unsuccessful.” (Cornell University et al., 2014: 48)

\section{Pillar 5: Business sophistication}

The fifth pillar is intended to capture the level of business sophistication to assess "how conducive firms are to innovation activity". Sub-pillar 5.1 on knowledge workers is built by four indicators: employment in knowledge-intensive services; the availability of formal training at the firm level; R\&D performed by business enterprise (BERD) as a percentage of GDP; and the percentage of gross expenditures of R\&D (GERD) financed by businesses. Further, it includes an indicator taken from the Graduate Management Admission Test (GMAT). "The total number of GMAT test takers (scaled by population aged 20 to 34 years old) [was] taken as a proxy for the entrepreneurial mindset of young graduates.”

Sub-pillar 5.2 on innovation linkages exploits data on business-university R\&D collaborations, "the prevalence of well-developed and deep clusters", the ratio of GERD financed from abroad, and "the number of deals on joint ventures and strategic alliances. The latter covers a total of 2,978 deals announced in 2013, with firms headquartered in 127 participating economies. In addition, the total number of Patent Cooperation Treaty (PCT) 
and national office published patent family applications filed by residents in at least three offices is included this year to proxy for international linkages.”

“The rationale behind sub-pillars 5.3 on knowledge absorption (an enabler) and 6.3 on knowledge diffusion (a result) - two sub-pillars designed to be mirror images of each other - is precisely that together they will reveal how good countries are at absorbing and diffusing knowledge. Sub-pillar 5.3 includes four statistics that are linked to sectors with high-tech content or are key to innovation: royalty and license fees payments as a percentage of total trade; high-tech imports (net of re-imports) as a percentage of total imports; imports of communication, computer and information services as a percentage of total trade; and net inflows of foreign direct investment (FDI) as a percentage of GDP.” (Cornell University et al., 2014: 48-49; some obvious mistakes are corrected - A.H.)

The name of this pillar is not explained, although it does not seem to be self-explanatory. It is not clear, either, why firms should be conducive to innovation activity. Usually analyses have a different logic: market and regulatory conditions, that is, factors external to the firms, can be conducive for - or hamper - innovation activities performed by businesses. Further, it is difficult to accept the ratio of GMAT test takers "as a proxy for the entrepreneurial mindset of young graduates". The name of sub-pillar 5.2 (innovation linkages) only partially matches its components, of which two concern R\&D activities, and a third one (on patents) is also more relevant to characterise R\&D activities than reflect innovation activities. Data on high-tech imports can only partially reflect knowledge absorption.

\section{Pillar 6: Knowledge and technology outputs}

The sixth pillar - just as all the previous ones - is composed of 3 sub-pillars. Sub-pillar 6.1 on knowledge creation "includes five indicators that are the result of inventive and innovative activities: patent applications filed by residents both at the national patent office and at the international level through the PCT; utility model applications filed by residents at the national office; scientific and technical published articles in peer-reviewed journals; and an economy's number of articles $(\mathrm{H})$ that have received at least $\mathrm{H}$ citations".

Sub-pillar 6.2 on knowledge impact is meant to measure "the impact of innovation activities at the micro- and macro-economic level or related proxies: increases in labour productivity, the entry density of new firms, spending on computer software, and the number of certificates of conformity with standard ISO 9001 on quality management systems issued”. The indicator on high- and medium-high-tech industrial output over total manufactures output is for the first time in this edition of the GII.

Sub-pillar 6.3 on knowledge diffusion "is the mirror image of the knowledge absorption sub-pillar of pillar 5 . It includes four statistics all linked to sectors with high-tech content or 
that are key to innovation: royalty and license fees receipts as a percentage of total trade; high-tech exports (net of re-exports) as a percentage of total exports (net of re-exports); exports of communication, computer and information services as a percentage of total trade; and net outflows of FDI as a percentage of GDP.” (Cornell University et al., 2014: 49-50)

The first sub-pillar is meant to be composed of indicators on "the result of inventive and innovative activities". Yet, most of these indicators are relevant to characterise $R \& D$ (and not innovation) activities. As for the knowledge impact sub-pillar, only one of the five components is related to knowledge impacts, and even that one is only partially: reflecting the impact of certain types of knowledge. As for knowledge diffusion, all the four components of that sub-pillar can indicate knowledge diffusion outside a given country (with certain limitations), and thus none of these seems to be relevant to characterise knowledge diffusion inside a given country.

\section{Pillar 7: Creative outputs}

The seventh pillar is also composed of 3 sub-pillars. The first one on intangible assets includes data on trademark applications by residents at the national office; trademark applications under the Madrid System by country of origin, and results obtained via two survey questions on the use of ICTs by businesses.

Sub-pillar 7.2 on creative goods and services is aimed to capture creativity and the creative outputs of an economy by using five indicators: cultural and creative services exports, including information services, advertising, market research and public opinion polling, and other personal, cultural, and recreational services (as a percentage of total trade); national feature films produced in a given country (per capita count); global entertainment and media output (per capita); printing and publishing output (as a percentage of total manufactures output); and creative goods exports (as a percentage of total trade).

Sub-pillar 7.3 on online creativity is composed of four indicators, all by population aged 15-69 years: generic (biz, info, org, net, and com) and country-code top level domains, average monthly edits to Wikipedia, and video uploads on YouTube. "Attempts made to strengthen this sub-pillar with indicators in areas such as blog posting, online gaming, the development of applications, and have so far proved unsuccessful." (Cornell University et al., 2014: 50-51)

It is not clear why "the use of ICTs in business and organizational models" is an output indicator. Only a small fraction of printing and publishing output is a creative output, with the bulk being the paper and other printing costs. It would be really costly to establish what portion of video uploads on YouTube can be regarded creative output. 
In sum, the GII is a remarkable effort both in terms of its geographic and thematic coverage, but it suffers from severe weaknesses concerning business innovation activities. In several cases there is a non-negligible mismatch between the 'headline' notions (pillars and their sub-pillars) and the actual components (indices or indicators) selected. Just as in the case of the EIS and IUS indicators, there is a bias towards R\&D-based (ST mode) innovations, and thus the DUI mode is eclipsed. It is even worse when $R \& D$ and innovation are conflated. As for describing and assessing social innovations, it would be difficult to use any of the 81 GII indicators as a relevant one.

\section{FURTHER METHODOLOGICAL CONSIDERATIONS}

\subsection{DEGREE OF NOVELTY, UNIT OF ANALYSIS}

A standard question in innovation surveys relates to the degree of novelty. A given innovation can be new to the firm, to the market (in a given country) or to the world. For pragmatic reasons, the Community Innovation Survey (CIS) uses only the first two categories: it would be too difficult to judge by the respondents - and subsequently check by experts - if a given innovation is new to the market in a given country or to the world. Of course, in rare cases, e.g. when the first digital camera, mobile phone or tablet is introduced, it is easier to establish that a certain product is new to the world, but even in these exceptional cases there could be some difficulties to establish which product variation (by which company) has been introduced first - and successfully.

This issue is closely related to the classification of innovations. In qualitative analyses the following categories can be used. New goods (that is, products or services) might represent an incremental or a radical change (innovation). If we consider further units (levels) of analysis we can also think of innovations at the level of technology systems, that is, a set of technologically and economically interconnected goods and processes, affecting several companies or an entire sector at the same time, occasionally leading to the emergence of new industries (e.g. canals, gas and electric light systems, plastic goods, electric household devices). Being dissatisfied with the notion of 'long waves' used in analysing business cycles (mainly by Kondratiev and Schumpeter), Freeman and Perez have elaborated on the notion of techno-economic paradigms, that is,

"the set of the most successful and profitable practices in terms of choice of inputs, methods and technologies, and in terms of organisational structures, business models and strategies. These mutually compatible practices, which turn into implicit principles and criteria for decision-making, develop in the process of using the new technologies, overcoming obstacles and finding more adequate procedures, routines and structures. The emerging heuristic routines and approaches are gradually internalised by engineers and managers, investors and bankers, sales and advertising people, entrepreneurs and consumers. In time, a shared logic is established; a new 'common sense' is accepted for investment decisions as well as for 
consumer choice. The old ideas are unlearned and the new ones become "normal." (Perez, 2010: 194)

Just to illustrate, the examples of such paradigmatic changes are the (first) industrial revolution; the age of steam and railways; the age of steel, electricity, and heavy engineering; the age of oil, automobile, and mass production; and more recently the age of infocommunications.

Some of these considerations might be useful when analysing social innovations in a qualitative way. Yet, compared to technological innovations, it is likely to be even more difficult to establish the degree of novelty of a given social innovation. But the degree of novelty seems to be of lesser importance in these cases: usually intellectual property rights are not an issue for social innovators. Of course, prestige - being inventive and obtaining acknowledgments for that - might play a role: it could give some impetus to be involved in certain social innovation projects. It is an empirical question to establish the role of prestige in these endeavours.

What seems to be perhaps more relevant - but probably even more difficult than in the case of technological innovations - is to identify whether a given social innovation is an 'isolated' new solution or - using the analogy of technology systems - a part of a new 'social system', that is, a set of socially, institutionally, organisationally, and economically interconnected social innovations, affecting several groups of people or an entire community (a neighbourhood, village, town or city) at the same time, occasionally leading to the emergence of new social structures, norms, institutions, behaviour, value systems and practices at a higher level of aggregation (e.g. sub-national regions, nations or even supranational regions [for example, the European Union]).

Some aspects of the notion of techno-economic paradigms are contested among economists and economic historians dealing with technological innovations on the one hand, and this notion is probably too complex, too demanding - too far-fetched - to be applied to analyse social innovations, on the other. One of its features could be considered, though, as a useful guiding principle when analysing social innovations, namely the interconnectedness of technological, organisational and business model innovations, together with the emergence of a new, widely accepted 'common sense'.

Most of the indicators and indices used to compile the Summary Innovation Index (EIS, IUS), the Global Innovation Index and the Technology Achievement Index (UNDP, 2001) reflect the macro level: these components are calculated by aggregating micro level data (e.g. economic indicators at firm level, while education indicators at the level of individuals). In contrast, social innovations can be monitored (observed) at a project level, and it is hardly 
possible to aggregate these data (observations) in a meaningful way to arrive at a macro level.

\subsection{INNOVATION ACTIVITIES, THEIR FRAMEWORK CONDITIONS AND IMPACTS}

In spite of the relatively long-established tradition in measuring business innovations and the significant efforts devoted to advance and standardise methods, there is a considerable lack of clarity whether a certain measurement or monitoring exercise (a set of indicators, data collection, measurement and analytical methods) is aimed at characterising (a) innovation activities (efforts) themselves, (b) the framework conditions (pre-requisites, available inputs, skills, etc.) of being innovative (or successful in innovation efforts), or (c) the economic, societal or environmental impacts of innovations. Given the complexity of innovation processes themselves, as well as that of economic, societal or environmental developments, it is certainly a major difficulty to attribute a certain economic, societal or environmental phenomenon as a direct (or major) effect of a given innovation project (or a set of them at an aggregated level).

These fundamental methodological difficulties certainly apply to social innovations, too, perhaps even a fortiori. Again, a noteworthy issue is the lack of conscious efforts to distinguish between measuring (a) social innovation activities (efforts) themselves, (b) the framework conditions (pre-requisites, available inputs, skills, norms, values, behavioural patterns, etc.) of being socially innovative, and (c) the economic, societal or environmental impacts of social innovations.

\subsection{COMPOSITE INDICATORS}

There is a fairly strong - sometimes implicit, at other times rather explicit - pressure to devise so-called composite indicators to compress information into a single figure in order to compile eye-catching, easy-to-digest scoreboards. A major source of complication is choosing an appropriate weight to be assigned to each component. By conducting sensitivity analyses of the 2005 European Innovation Scoreboard (EIS), Grupp and Schubert (2010: 72) have shown how unstable the rank configuration is when the weights are changed. Besides assigning weights, three other ranking methods are also widely used, namely: unweighted averages, Benefit of the Doubt (BoD) and principal component analysis. Comparing these ranking methods, the authors conclude: "Not only utilizing the rankings highly sensitive to weighting (...), but even using accepted approaches like BoD or factor analysis may result in drastically changing rankings." (ibid: 74) Hence, they propose using multidimensional representations, e.g. spider charts to reflect the multidimensional character of innovation processes and performance. That would enable analysts and policy-makers to identify strengths and weaknesses, that is, more precise targets for policy actions. (ibid: 77) 
Other researchers also emphasise the need for a sufficiently detailed characterisation of innovation processes. For example, a family of five indicators - R\&D, design, technological, skill, and innovation intensities - offers a more diversified picture on innovativeness than the Summary Innovation Index of the EIS. (Laestadius et al., 2005) Using Norwegian data they demonstrate that the suggested method can capture variety in knowledge formation and innovativeness both within and between sectors. It thus supports a more accurate understanding of creativity and innovativeness inside and across various sectors, directs policy-makers' attention to this diversity (suppressed by the OECD classification of sectors), and thus can better serve policy needs.

These considerations do seem to apply to social innovations, too.

\section{SUMMARY AND CONCLUSIONS}

This paper has reviewed business innovation indicators from theoretical and policy perspectives. It has discussed two widely used sets of innovation indicators, their context and shortcomings and also considered if they can be followed as a 'model' when designing social innovation indicators.

The main findings can be summarised as follows. Various economics paradigms treat (business) innovation (if not neglect it altogether) in diametrically different ways: they consider different notions as crucial ones (e.g. risk vs. uncertainty, information vs. various forms, types and sources of knowledge, skills and learning capabilities and processes); offer diverse justifications (policy rationales) for state interventions; interpret the significance of various types of inputs, efforts, and results differently, and thus - implicitly - identify different 'targets' for measurement, monitoring and analytical purposes (what phenomena, inputs, capacities, processes, outcomes and impacts are to be measured and assessed).

The science-push model of innovation, reinforced by the sophisticated - and thus appealing and compelling - models of mainstream economics emphasises the economic impacts of R\&D-based innovation efforts, advances the market failure argument and the concomitant set of policy advice. Hence it focuses the attention of decision-makers and analysts to the so-called ST mode of innovation. Measurement and monitoring systems influenced by this way of thinking - most notably the Innovation Union Scoreboard of the European Commission, but to a significant extent several other attempts, too, e.g. the Global Innovation Index, and the Technology Achievement Index compiled for the 2001 edition of the Human Development Report - tend to pay attention mainly to the ST mode of innovation, at the expense of the so-called DUI mode of innovation. It is a major concern, 
however, as the latter one is equally important from the point of view of enhancing productivity, creating jobs and improving competitiveness.

In contrast, evolutionary economics of innovation - in line with the networked model of innovation - stresses the systemic nature of innovation and thus advocates rectifying any systemic failure that hinders the generation, circulation and exploitation of any type of knowledge required for successful innovation processes. This way of thinking has influenced the measurement and monitoring practices of the European Commission or the OECD to a significantly lesser extent than mainstream economics.

In sum, the IUS indicators in principle could be useful in settings where the dominant mode of innovation is the ST mode. In practice, however, both the ST and DUI modes of innovation are fairly important. (Jensen et al., 2007) Moreover, the so-called Summary Innovation Index - calculated from the IUS indicators - does not provide sufficient information to assess a given innovation system: its low value could reflect either a low level of innovation activities altogether or a low level of R\&D-based innovation activities (while other types of innovations are abundant). Yet, that is a fairly important distinction both from an analytical and a practical (policy) point of view: these two innovation systems are fundamentally different. Analysts and policy-makers dealing with innovation, therefore, should pay attention to both R\&D-based (ST) and non-R\&D-based (DUI) innovations.

Further, while social innovations can certainly rely on R\&D-based technological innovations, their essence tends to be organisational, managerial and behavioural changes. The IUS indicators do not capture these types of changes. More generally, analysts and decision-makers should be aware of the diversity of social innovations, too, in terms of their nature, drivers, objectives, actors, and process characteristics.

An assessment of the 81 indicators used to compile the Global Innovation Index has shown that it would not be a fruitful effort to rely on any of those indicators to describe and characterise social innovations.

The Technology Achievement Index, presented in the 2001 edition of the Human Development Report (UNDP, 2001), has not been discussed in this paper, but it is worth recalling that it does not offer a promising approach, either. It is not a comprehensive measure: it considers only certain types of technological achievements and not necessarily those that are the most relevant from the point of view of human development. (ChiapperoMartinetti, 2015; see also Desai et al., 2002)

Some more general methodological lessons, however, can be distilled from the efforts devoted to measure business innovations. The first one concerns the use of composite indicators. Scoreboards and league tables compiled following the science-push logic, based 
on a composite indicator to establish rankings, and published by supranational organisations, can easily lead to 'lock-in' situations. National policy-makers - and politicians, in particular - are likely to pay much more attention to their country's position on a scoreboard than to nuanced assessments or policy recommendations in lengthy documents, and hence this inapt logic is 'diffused' and strengthened at the national level, too, preventing policy learning and devising appropriate policies. Despite the likely original intention, that is, to broaden the horizon of decision-makers by offering internationally comparable data, these scoreboards and league tables strengthen a narrow-minded, simplifying approach.

In other words, given the diversity among innovation systems, one should be very careful when trying to draw policy lessons from the 'rank' of a country as 'measured' by a composite indicator. A scoreboard can only be constructed by using the same set of indicators across all countries, and by applying an identical method to calculate the composite index. Yet, it is important to realise that poor performance signalled by a composite indicator, and leading to a low rank on a certain scoreboard, does not automatically identify the area(s) necessitating the most urgent policy actions.

In contrast, a high rank on a scoreboard, e.g. Sweden's first place on the 2013 Innovation Union Scoreboard does not necessarily reflect a satisfactory performance. By taking into account the input and output nature of various IUS indicators Edquist and ZabalaIturriagagoitia (2015) calculated the productivity of national innovation systems covered by the IUS and using this assessment - which is, no doubt, highly relevant from a policy point of view - Sweden ranks a mere 24.

Analysts and policy-makers, therefore, need to avoid the trap of paying too much attention to simplifying ranking exercises. Instead, it is of utmost importance to conduct detailed, thorough comparative analyses, identifying the reasons for a disappointing performance, as well as the sources of - opportunities for - balanced, and sustainable, socioeconomic development.

Second, the degree of novelty and the unit of analysis are interrelated issues when business innovations are surveyed. It looks a rather difficult task to establish the degree of novelty of a given social innovation. Actually, this issue seems to be of lesser importance in these cases: intellectual property rights are seldom an issue for social innovators. Prestige obtained by being acknowledged as a creative social innovator - might, however, play a role: it could be perceived as an incentive to initiate social innovation projects. No doubt, it is an empirical question to establish the role of prestige in these endeavours. 
It could be also an interesting - but certainly a demanding - research question to identify whether a given social innovation is a standalone new solution or - using the analogy of technology systems - a part of a new 'social system', that is, a set of socially, institutionally, organisationally, and economically interconnected social innovations, affecting several groups of people or an entire community (a neighbourhood, village, town or city) at the same time, occasionally leading to the emergence of new social structures, norms, institutions, behaviour, value systems and practices at a higher level of aggregation (e.g. subnational regions, nations or even supra-national regions [for example, the European Union]).

Efforts aimed at measuring social innovation cannot rely a similarly long tradition. The TEPSIE project has been a significant effort to this end. Although the proposed TEPSIE framework for measuring social innovation (Bund et al., 2013) has not been analysed in this paper, it should be noted that its first pillar, called entrepreneurial activity is not specific to social innovation, on the one hand, and somewhat neglects non-entrepreneurial social innovation activities, on the other. Its second pillar, called field-specific output and outcomes, offers useful hints, but we are faced by the usual attribution problem in the case of social innovations, too. The third pillar is concerned with framework conditions. The structure of the TEPSIE indicators prompts a more general caveat: analysts and policymakers need to be aware of the differences between measuring (a) social innovation activities (efforts) themselves, (b) the framework conditions (pre-requisites, available inputs, skills, norms, values, behavioural patterns, etc.) of being socially innovative, and (c) the economic, societal or environmental impacts of social innovations.

\section{REFERENCES}

Arrow, K.J. (1962): The Economic Implications of Learning by Doing, The Review of Economic Studies, 29 (3): 155-173

Balconi, M., S. Brusoni, L. Orsenigo (2010): In defence of the linear model: An essay, Research Policy, 39 (1), 1-13

Baumol, W.J. (2002): The Free-Market Innovation Machine: Analyzing the growth miracle of capitalism, Princeton: Princeton University Press

Baumol, W., R. Litan, C. Schramm (2007): Good Capitalism, Bad Capitalism, and the Economics of Growth and Prosperity, New Haven: Yale University Press

Bender, G., D. Jacobson, P.L. Robertson (eds) (2005): Non-Research-Intensive Industries in the Knowledge Economy, Perspectives on Economic and Social Integration - Journal for Mental Changes, special issue, XI (1-2)

Bleda, M. and P. del Río (2013): The market failure and the systemic failure rationales in technological innovation systems, Research Policy, 42 (5): 1039-1052

Bund, E., D-K. Hubrich, B. Schmitz, G. Mildenberger, G. Krlev (2013): Blueprint of social innovation metrics - contributions to an understanding of opportunities and challenges of social innovation measurement, deliverable 2.4 of the TEPSIE project: The theoretical, 
empirical and policy foundations for building social innovation in Europe, European Commission 7th Framework Programme

Bush, V. (1945): Science: the Endless Frontier, Washington DC: US Government Printing Office

Caraça, J., B-Å. Lundvall, S. Mendonça (2009): The changing role of science in the innovation process: From Queen to Cinderella?, Technological Forecasting and Social Change, 76 (6): 861-867

Castellacci, F. (2008a): Innovation and the competitiveness of industries: Comparing the mainstream and the evolutionary approaches, Technological Forecasting and Social Change, 75 (7): 984-1006

Castellacci, F. (2008b): Technological paradigms, regimes and trajectories: Manufacturing and service industries in a new taxonomy of sectoral patterns of innovation, Research Policy, 37 (6-7): 978-994

Chiappero-Martinetti, E. (2015): Relationship between innovation/technology and human development, contribution to WP3 of the CrESSI project, Pavia: mimeo

Cornell University, INSEAD and WIPO (2014): The Global Innovation Index 2014: The Human Factor in Innovation, Fontainebleau, Ithaca, and Geneva: Cornell University, INSEAD and WIPO

Desai, M., S. Fukuda-Parr, J. Johansson, F. Sagasti, (2002): Measuring Technology Achievement of Nations and the Capacity to Participate in the Network Age, Journal of Human Development, 3 (1): 95-122

Di Stefano, G., A. Gambardella, G. Verona (2012): Technology push and demand pull perspectives in innovation studies: Current findings and future research directions, Research Policy, 41 (8): 1283-1295

Dodgson, M. and R. Rothwell (eds) (1994): The Handbook of Industrial Innovation, Cheltenham: Edward Elgar

Dodgson, M., D.M. Gann, N. Phillips (eds) (2014): The Oxford Handbook of Innovation Management, Oxford: Oxford University Press

Dosi, G. (1988a): The nature of the innovative process, in: Dosi et al. (eds) (1988), pp. 221238

Dosi, G. (1988b): Sources, procedures and microeconomic effects of innovation, Journal of Economic Literature, 24 (4): 1120-1171

Dosi, G., C. Freeman, R.R. Nelson, G. Silverberg, L. Soete (eds) (1988): Technical Change and Economic Theory, London: Pinter

EC (2002): 2002 European Innovation Scoreboard, Technical Paper No 6, Methodology

Report, Brussels: European Commission, Enterprise Directorate-General

EC (2003a): European Innovation Scoreboard 2003, CORDIS focus supplement No. 20, Luxembourg: European Commission, Enterprise Directorate-General

EC (2003b): 2003 European Innovation Scoreboard, Technical Paper No 1, Indicators and Definitions, Brussels: European Commission, Enterprise Directorate-General

EC (2004): 2004 European Innovation Scoreboard, Methodology Report, Brussels: European Commission, Enterprise Directorate-General

EC (2005): Methodology Report on European Innovation Scoreboard 2005, Brussels: European Commission, Enterprise Directorate-General

EC (2009): European Innovation Scoreboard 2008: Comparative analysis of innovation performance, Luxembourg: Office for Official Publications of the European Communities

EC (2010): European Innovation Scoreboard (EIS) 2009: Comparative analysis of innovation performance, Luxembourg: Office for Official Publications of the European Communities 
EC (2012): Innovation Union Scoreboard 2011, Directorate-General for Enterprise and Industry, Brussels: European Commission

EC (2013a): Innovation Union Scoreboard 2013, Directorate-General for Enterprise and Industry, Brussels: European Commission

EC (2013b): Research and Innovation performance in EU Member States and Associated countries: Innovation Union progress at country level, Luxembourg: Office for Official Publications of the European Communities

EC (2013c): State of the Innovation Union 2012: Accelerating change, Luxembourg: Office for Official Publications of the European Communities

EC (2013d): European Competitiveness Report 2013: Towards Knowledge-driven Reindustrialisation, Luxembourg: Office for Official Publications of the European Communities

EC (2014): Innovation Union Scoreboard 2014, Directorate-General for Enterprise and Industry, Brussels: European Commission

EC (2015): Innovation Union Scoreboard 2014, Directorate-General for Internal Market, Industry, Entrepreneurship and SMEs, Brussels: European Commission

Edquist, C. (2011): Design of innovation policy through diagnostic analysis: identification of systemic problems or (failures), Industrial and Corporate Change, 20 (6): 1725-1753

Edquist, C. (ed.) (1997): Systems of Innovations: Technologies, institutions and organizations, London: Pinter

Edquist, C. and J.M. Zabala-Iturriagagoitia (2015): The Innovation Union Scoreboard is Flawed: The case of Sweden - not being the innovation leader of the EU, CIRCLE Papers in Innovation Studies, No. 2015/16

Ergas, H. (1986): Does Technology Policy Matter? Centre for European Policy Studies, CEPS Papers No. 29, Brussels

Ergas, H. (1987): The importance of technology policy, in: Dasgupta, P., Stoneman, P. (eds): Economic Policy and Technological Performance, Cambridge, MA: Cambridge UP, pp. 5196

Fagerberg, J., D.C. Mowery, R.R. Nelson (eds) (2005): The Oxford Handbook of Innovation, Oxford: Oxford University Press

Fagerberg. J., M. Fosaas, M. Bell, B. Martin (2011): Christopher Freeman: social science entrepreneur, Research Policy, 40 (7): 897-916

Fagerberg, J., Fosaas, M., Sapprasert, K. (2012): Innovation: Exploring the knowledge base, Research Policy, 41 (7): 1132-1153

Foray, D. (ed.) (2009): The New Economics of Technology Policy, Cheltenham: Edward Elgar

Freeman, C. (1991): Networks of innovators, a synthesis of research issues, Research Policy, 20 (5): 499-514

Freeman, C. (1994): The economics of technical change: A critical survey, Cambridge Journal of Economics, 18 (5): 463-514

Freeman, C. (1995): The "National System of Innovation" in historical perspective, Cambridge Journal of Economics, 19 (1): 5-24

Freeman, C. and L. Soete (1997): The Economics of Industrial Innovation (3rd edition), London: Pinter

Godin, B. (2006): The Linear Model of Innovation: The Historical Construction of an Analytical Framework, Science, Technology \& Human Values, 31 (6): 639-667

Godin, B. (2008): The moral economy of technology indicators, in: Hirsch-Kreinsen, H. and D. Jacobson (eds) (2008), pp. 64-84

Grupp, H. (1998): Foundations of the Economics of Innovation: Theory, measurement and practice, Cheltenham: Edward Elgar 
Grupp, H. and T. Schubert (2010): Review and new evidence on composite innovation indicators for evaluating national performance, Research Policy, 39 (1): 67-78

Hall, B.H. and N. Rosenberg (eds) (2010): Economics of Innovation, Amsterdam: NorthHolland

Havas, A. (2015a): The persistent high-tech myth in the EC policy circles: Implications for the EU10 countries, Institute of Economics CERS HAS Discussion Papers MT-DP 2015/17

Havas, A. (2015b): How does social innovation challenge neo-classical assumptions regarding technological innovation? in: C. Houghton Budd, C.W.M. Naastepad, and C. P. van Beers (eds): Report Contrasting CrESSI's Approach of Social Innovation with that of Neoclassical Economics, CrESSI D1.3, pp. 40-46

Hatzichronoglou, T. (1997): Revision of the High-Technology Sector and Product Classification, OECD STI Working Papers, 1997/2

Hirsch-Kreinsen, H. and D. Jacobson (eds) (2008): Innovation in Low-Tech Firms and Industries, Cheltenham: Edward Elgar

Hirsch-Kreinsen, H. and I. Schwinge (eds) (2014): Knowledge-intensive Entrepreneurship in Low-Tech Industries, Cheltenham: Edward Elgar

Hirsch-Kreinsen, H., D. Jacobson, S. Laestadius (eds) (2005): Low Tech Innovation in the Knowledge Economy, Frankfurt: Peter Lang

Hirsch-Kreinsen, H., D. Jacobson, S. Laestadius, K. Smith (2005): Low and Medium Technology Industries in the Knowledge Economies: The Analytical Issues, in: HirschKreinsen et al. (eds) (2005), pp. 11-29

Hollanders, H. and S. Tarantola (2011): Innovation Union Scoreboard 2010 - Methodology report, ProInno Europe, InnoMetrics

Jensen, M.B., B. Johnson, E. Lorenz, B-Å. Lundvall (2007): Forms of knowledge and modes of innovation, Research Policy, 36 (5): 680-693

Kaloudis, A., T. Sandven, K. Smith (2005): Structural change, growth and innovation: The roles of medium and low-tech industries, 1980-2002, in: Bender et al. (eds) (2005), pp. 49-73

Klevorick, A.K., R.C. Levin, R.R. Nelson, S.G. Winter (1995): On the sources and significance of interindustry differences in technical opportunities, Research Policy, 24 (2): 185-205

Kline, S.J. and N. Rosenberg (1986): An Overview of Innovation, in: Landau, R., Rosenberg, N. (eds): The Positive Sum Strategy: Harnessing Technology for Economic Growth, Washington: National Academy Press, pp. 275-305

Laestadious, S., T.E. Pedersen, T. Sandven (2005): Towards a new understanding of innovativeness - and of innovation based indicators, in: Bender et al. (eds) (2005), pp. 75121

Lazonick, W. (2013): The Theory of Innovative Enterprise: Methodology, Ideology, and Institutions, in: J.K. Moudud, C. Bina, P.L. Mason (eds): Alternative Theories of Competition: Challenges to the Orthodoxy, London: Routledge, pp. 127-159

Lundvall, B-Å. (ed.) (1992): National Systems of Innovation: Towards a Theory of Innovation and Interactive Learning, London: Pinter

Lundvall, B-Å. and S. Borrás (1999): The Globalising Learning Economy: Implications for Innovation Policy, Luxembourg: Office for Official Publications of the European Communities

Malerba, F. (2002): Sectoral systems of innovation and production, Research Policy, $\mathbf{3 1}$ (2): 247-264

Martin, B. (2012): The evolution of science policy and innovation studies, Research Policy, 41 (7): 1219-1239 
Mendonça, S. (2009): Brave old world: Accounting for 'high-tech' knowledge in 'low-tech' industries, Research Policy, 38 (3): 470-482

MERIT and EC JRC (2006): European Innovation Scoreboard 2006: Comparative analysis of innovation performance, ProInno Europe, InnoMetrics

MERIT and EC JRC (2008): European Innovation Scoreboard 2007: Comparative analysis of innovation performance, ProInno Europe, InnoMetrics

Metcalfe, S. (1998): Evolutionary Economics and Creative Destruction, London: Routledge

Mowery, D.C. (2009): Plus ça change: Industrial R\&D in the "third industrial revolution", Industrial and Corporate Change, 18 (1): 1-50

Mowery, D.C. and R.R. Nelson (eds) (1999): Sources of Industrial Leadership: Studies of Seven Industries, Cambridge: Cambridge University Press

Nelson, R.R. (1995): Recent evolutionary theorizing about economic change, Journal of Economic Literature, 33 (1): 48-90

Nelson, R.R. (ed.) (1993): National Innovation Systems: A comparative study, Oxford: Oxford University Press

OECD (1992): TEP: The Key Relationships, Paris: OECD

OECD (1998): New Rationale and Approaches in Technology and Innovation Policy, STI Review, No. 22

OECD (2001): Innovative Networks: Co-operation in national innovation systems, Paris: OECD

OECD (2002): Frascati Manual: Proposed Standard Practice for Surveys on Research and Experimental Development, 6th edition, Paris: OECD

OECD (2005): Oslo Manual: Guidelines for Collecting and Interpreting Innovation Data, 3rd edition, Paris: OECD

Pavitt, K. (1984): Sectoral patterns of technical change: towards a taxonomy and theory, Research Policy, 13 (6): 343-373

Pavitt, K. (1999): Technology, Management and Systems of Innovation, Cheltenham: Edward Elgar

Peneder, M. (1999): The Austrian Paradox: "Old" structures but high performance? Austrian Economic Quarterly, 4 (4): 239-247

Peneder, M. (2010): Technological regimes and the variety of innovation behaviour: Creating integrated taxonomies of firms and sectors, Research Policy, 39 (3): 323-334

Perez, C. (2010): Technological revolutions and techno-economic paradigms, Cambridge Journal of Economics, 34 (1): 185-202

Robertson, P. and K. Smith (2008): Distributed knowledge bases in low- and medium technology industries, in: Hirsch-Kreinsen, H., Jacobson, D. (eds) (2008), pp. 93-117

Robertson, P., K. Smith, N. von Tunzelmann (2009): Innovation in low- and mediumtechnology industries, Research Policy, 38 (3): 441-446

Rosenberg, N. (1982): Inside the black box: Technology and economics, Cambridge: Cambridge University Press

Sandven, T., K. Smith, A. Kaloudis (2005): Structural change, growth and innovation: the roles of medium and low-tech industries, 1980-2000, in: Hirsch-Kreinsen et al. (eds) (2005), pp. 31-59

Smith, K. (2000): Innovation as a Systemic Phenomenon: Rethinking the Role of Policy, Enterprise \& Innovation Management Studies, 1 (1): 73-102

Smith, K. (2002): What is the "Knowledge Economy"? Knowledge intensity and distributed knowledge bases, UNU/INTECH Discussion Paper Series, 2002-6

Smith, K. (2005): Measuring Innovation, in: Fagerberg et al. (eds) (2005), pp. 148-177 
Tidd, J., J. Bessant, K. Pavitt (1997): Managing Innovation: Integrating technological, market and organizational change, Chichester: John Wiley \& Sons

UNDP (2001): Human Development Report: Making new technologies work for human development, Oxford: Oxford University Press

von Hippel, E. (1988): The Sources of Innovation, Oxford: Oxford University Press

von Tunzelman, N. (1995): Technology and Industrial Progress: The foundations of economic growth, Aldershot: Edward Elgar

von Tunzelmann, N. and V. Acha (2005): Innovation in "Low-Tech" Industries, in: Fagerberg et al. (eds) (2005), pp. 407-432 
Figure A1

Highly important 'business' sources of information for product and process innovation, EU members, 2006-2008

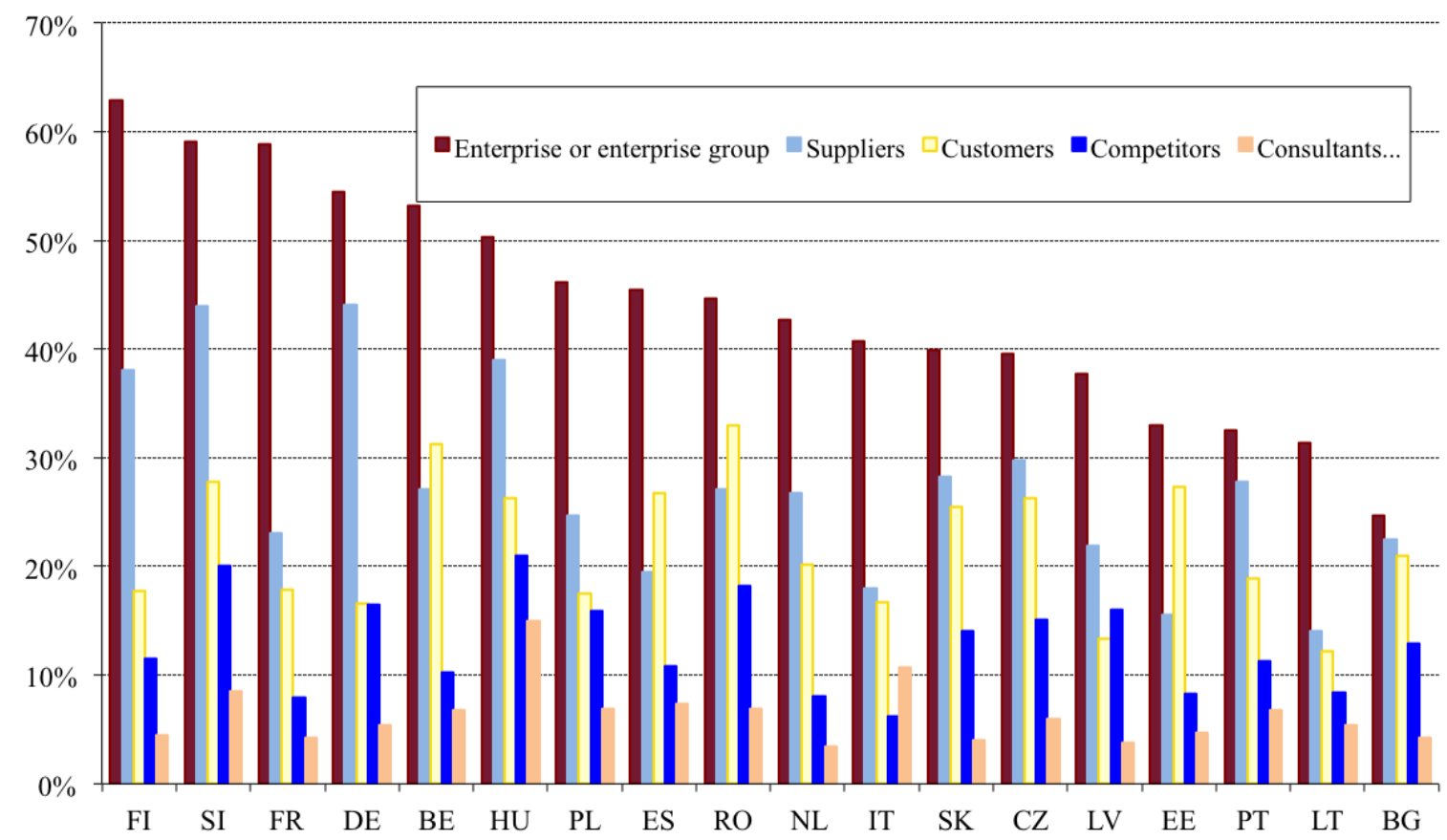

Source: Eurostat, CIS2008

Note: Data for Cyprus, Luxembourg and Malta are not included in this figure.

Figure A2

Highly important 'scientific' sources of information for product and process innovation, EU members, 2006-2008

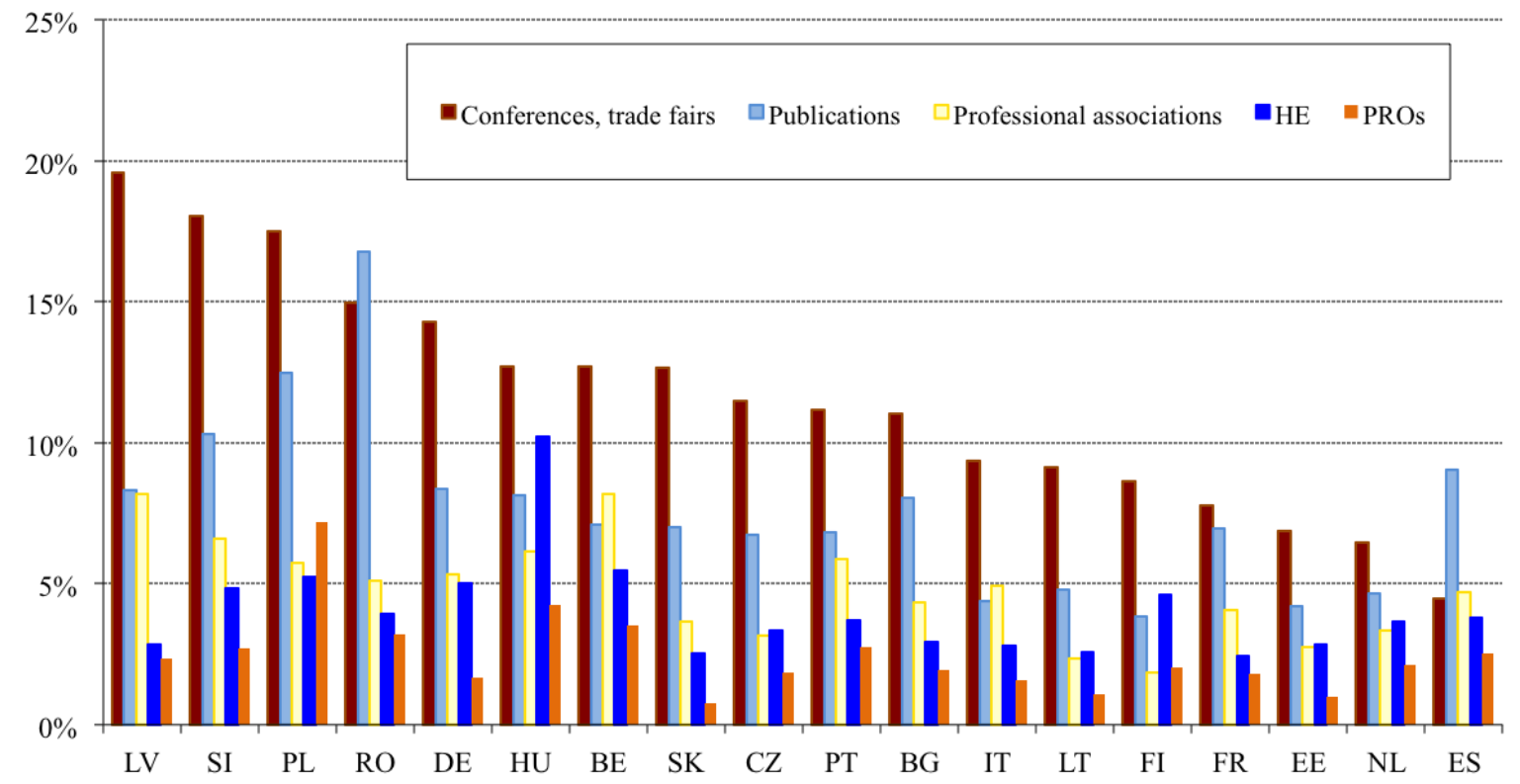

Source: Eurostat, CIS2008

Note: Data for Cyprus, Luxembourg and Malta are not included in this figure. 
Figure A3

Highly important 'business' sources of information for product and process innovation, EU members, 2008-2010

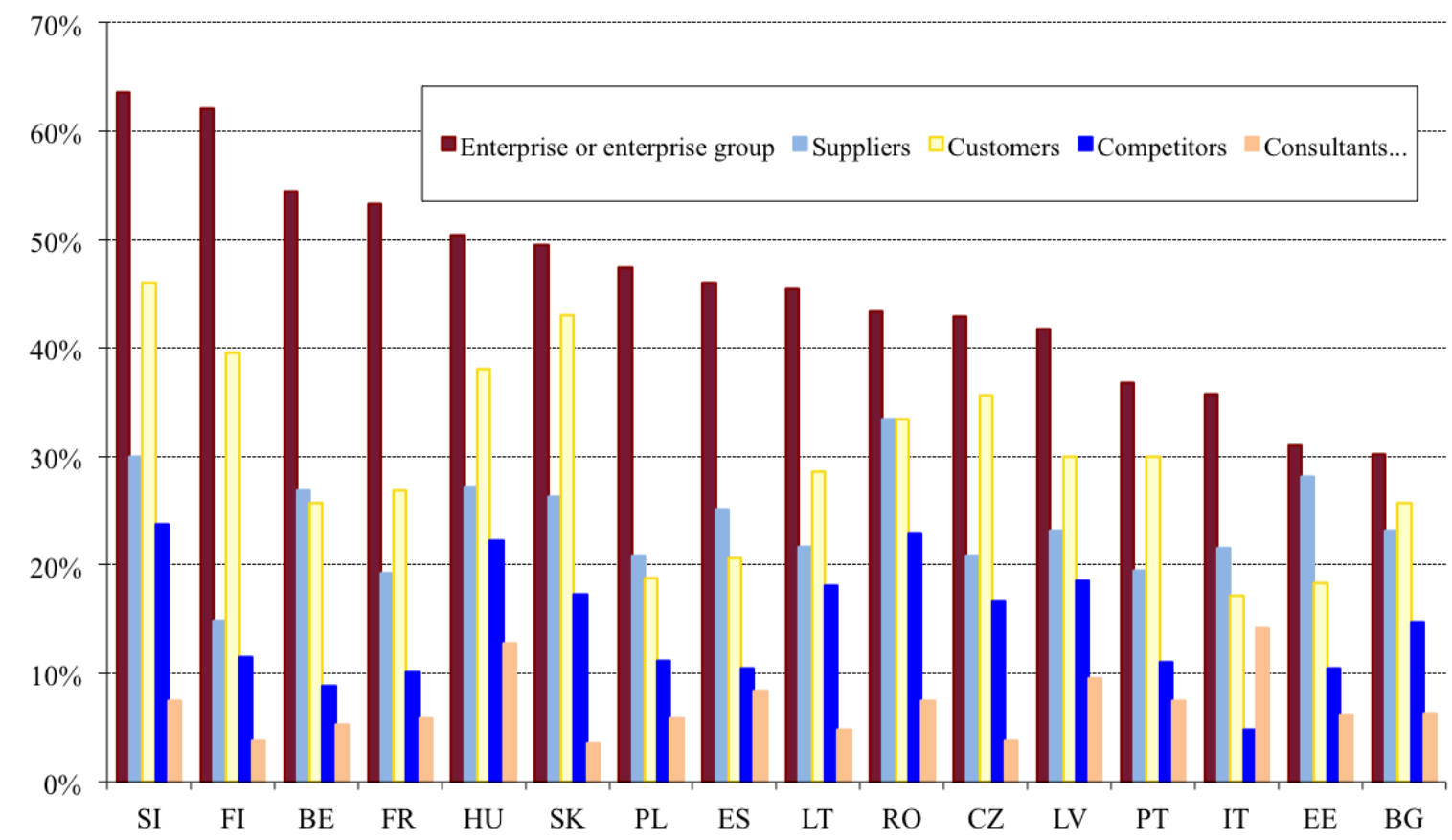

Source: Eurostat, CIS2010

Note: Data for Cyprus, Luxembourg and Malta are not included in this figure.

Figure A4

Highly important 'scientific' sources of information for product and process innovation, EU members, 2008-2010

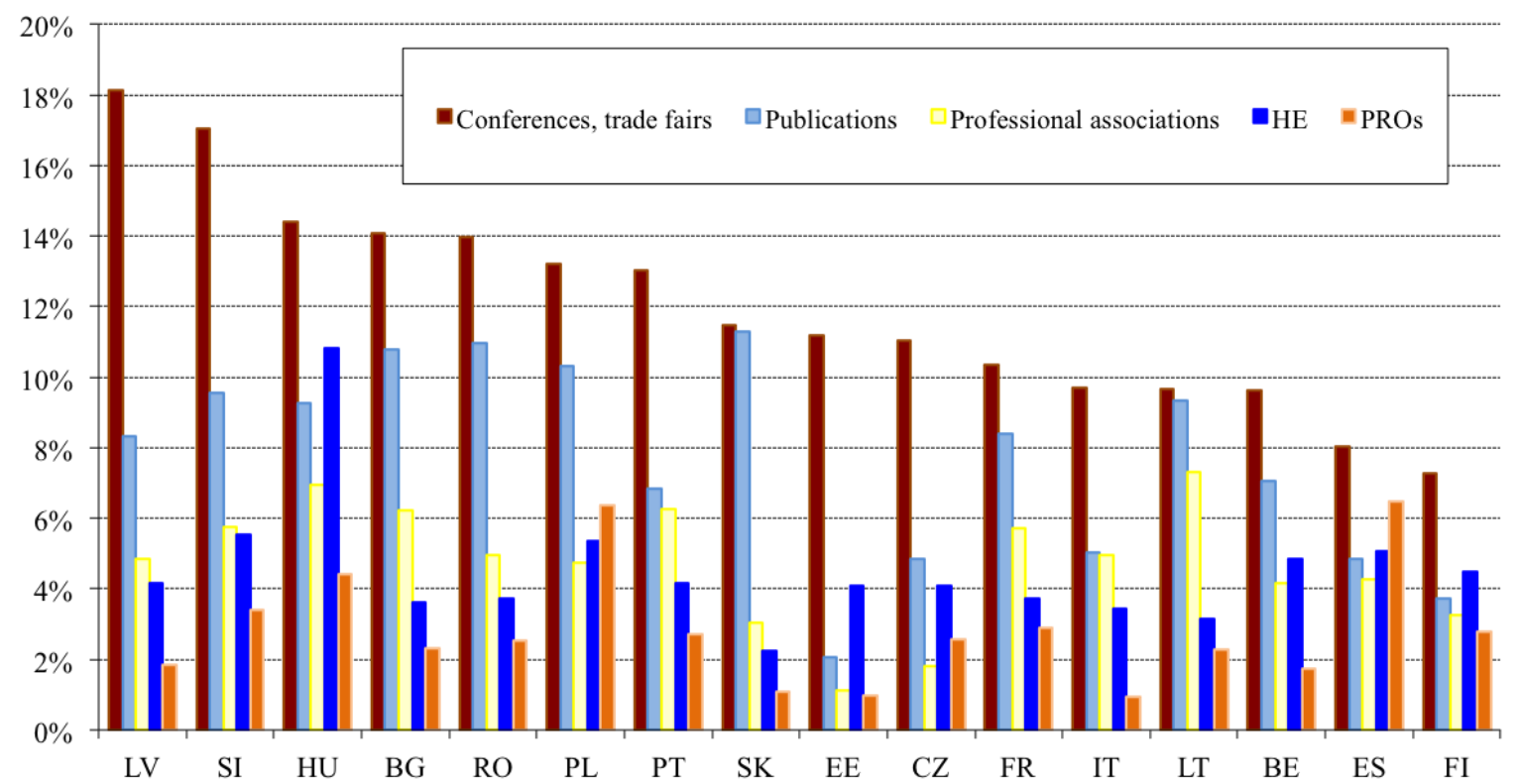

Source: Eurostat, CIS2010

Note: Data for Cyprus, Luxembourg and Malta are not included in this figure. 


\section{APPENDIX 2: THE EIS AND IUS INDICATORS}

The indicators used in particular editions of the EIS and IUS are presented and assessed in this Appendix, except for the first (2003) and last (2015) editions, which are presented in the main body of this report. The indicators used in 2006 and 2007 were identical, and thus are presented in a single table (Table A4). Further, the indicators used for the 2010, 2011 and 2013 editions of the Innovation Union Scoreboard were also identical, and thus these are presented in Table A7. ${ }^{18}$

18 The numbering convention was changed in 2013: in that year IUS 2013 was published, while continuing the previous convention it would have been called IUS 2012. 
The 2003 European Innovation Scoreboard indicators

\begin{tabular}{|c|c|c|}
\hline & $\begin{array}{c}\text { Relevance } \\
\text { for R\&D- } \\
\text { based } \\
\text { innovation }\end{array}$ & $\begin{array}{c}\text { Relevance } \\
\text { for non- } \\
\text { R\&D- } \\
\text { based } \\
\text { innovation }\end{array}$ \\
\hline \multicolumn{3}{|l|}{1 Human resources } \\
\hline $\begin{array}{l}\text { S\&E graduates (ISCED } 5 \text { a and above) per } 1000 \text { population aged 20- } \\
29\end{array}$ & $\mathrm{X}$ & \\
\hline Population with tertiary education (\% of $25-64$ years age class) & $\mathrm{b}$ & $\mathrm{b}$ \\
\hline Participation in life-long learning (\% of $25-64$ years age class) & $\mathrm{b}$ & $\mathrm{b}$ \\
\hline $\begin{array}{l}\text { Employment in medium-high and high-tech manufacturing (\% of } \\
\text { total workforce) }\end{array}$ & $\mathrm{X}$ & \\
\hline $\begin{array}{l}\text { Employment in high-tech services (\% of total workforce) } \\
2 \text { Knowledge creation }\end{array}$ & $\mathrm{X}$ & \\
\hline Public R\&D expenditures (GERD - BERD) (\% of GDP) & $\mathrm{X}$ & \\
\hline Business expenditures on R\&D (BERD) (\% of GDP) & $\mathrm{X}$ & \\
\hline EPO high-tech patent applications (per million population) & $\mathrm{X}$ & \\
\hline USPTO high-tech patent applications (per million population) & $\mathrm{X}$ & \\
\hline EPO patent applications (per million population) & $\mathrm{x}$ & \\
\hline USPTO patents granted (per million population) & $\mathrm{x}$ & \\
\hline \multicolumn{3}{|l|}{3 Transmission and application of knowledge } \\
\hline $\begin{array}{l}\text { SMEs innovating in-house (\% of manufacturing and \% of services } \\
\text { SMEs) }\end{array}$ & $\mathrm{b}$ & $\mathrm{b}$ \\
\hline $\begin{array}{l}\text { SMEs involved in innovation co-operation (\% of manufacturing and } \\
\% \text { of services SMEs) }\end{array}$ & $\mathrm{b}$ & $\mathrm{b}$ \\
\hline $\begin{array}{l}\text { Innovation expenditures (\% of all turnover in manufacturing and \% } \\
\text { of all turnover in services) }\end{array}$ & $\mathrm{b}$ & $\mathrm{b}$ \\
\hline \multicolumn{3}{|l|}{4 Innovation finance, output and markets } \\
\hline Share of high-tech venture capital investment & $\mathrm{X}$ & \\
\hline Share of early stage venture capital in GDP & $\mathrm{x}$ & \\
\hline $\begin{array}{l}\text { Sales of 'new to market' products (\% of all turnover in manufacturing } \\
\text { and \% of all turnover in services) }\end{array}$ & $\mathrm{b}$ & $\mathrm{b}$ \\
\hline $\begin{array}{l}\text { Sales of 'new to the firm but not new to the market' products (\% of all } \\
\text { turnover in manufacturing and \% of all turnover in services) }\end{array}$ & $\mathrm{b}$ & $\mathrm{b}$ \\
\hline $\begin{array}{l}\text { Internet access/ use (composite of home internet access and the } \\
\text { share of SMEs with own website) }\end{array}$ & $\mathrm{b}$ & $\mathrm{b}$ \\
\hline ICT expenditures (\% of GDP) & $\mathrm{b}$ & $\mathrm{b}$ \\
\hline Share of manufacturing value-added in high-tech & $\mathrm{X}$ & \\
\hline
\end{tabular}

Legend:

$\mathrm{X}$ : only relevant

$\mathrm{x}$ : mainly relevant

b: relevant for both types

Source: own compilation, drawing on the detailed definition of indicators, EC (2003b)

Notes: Public R\&D expenditures do not equal to GERD - BERD; rather, it should be the sum of governmentfunded parts of BERD, GOVERD, and HERD 
The 2004 European Innovation Scoreboard indicators

\begin{tabular}{|c|c|c|}
\hline & $\begin{array}{c}\text { Relevance } \\
\text { for R\&D- } \\
\text { based } \\
\text { innovation }\end{array}$ & $\begin{array}{c}\text { Relevance } \\
\text { for non- } \\
\text { R\&D- } \\
\text { based } \\
\text { innovation } \\
\end{array}$ \\
\hline \multicolumn{3}{|l|}{1 Human resources } \\
\hline $\begin{array}{l}\text { S\&E graduates (ISCED 5a and above) per } 1000 \text { population aged 20- } \\
29\end{array}$ & $\mathrm{X}$ & \\
\hline Population with tertiary education (\% of $25-64$ years age class) & $\mathrm{b}$ & $\mathrm{b}$ \\
\hline Participation in life-long learning (\% of $25^{-64}$ years age class) & $\mathrm{b}$ & $\mathrm{b}$ \\
\hline $\begin{array}{l}\text { Employment in medium-high and high-tech manufacturing (\% of } \\
\text { total workforce) }\end{array}$ & $\mathrm{X}$ & \\
\hline $\begin{array}{l}\text { Employment in high-tech services (\% of total workforce) } \\
2 \text { Knowledge creation }\end{array}$ & $\mathrm{X}$ & \\
\hline Public R\&D expenditures (GERD - BERD) (\% of GDP) & $\mathrm{X}$ & \\
\hline Business expenditures on R\&D (BERD) (\% of GDP) & $\mathrm{X}$ & \\
\hline EPO high-tech patent applications (per million population) & $\mathrm{X}$ & \\
\hline USPTO high-tech patents granted (per million population) & $\mathrm{X}$ & \\
\hline EPO patent applications (per million population) & $\mathrm{x}$ & \\
\hline USPTO patents granted (per million population) & $\mathrm{x}$ & \\
\hline \multicolumn{3}{|l|}{3 Transmission and application of knowledge } \\
\hline SMEs innovating in-house (\% of all SMEs) & $\mathrm{b}$ & $\mathrm{b}$ \\
\hline SMEs involved in innovation co-operation (\% of all SMEs) & $\mathrm{b}$ & $\mathrm{b}$ \\
\hline Innovation expenditures (\% of all turnover) & $\mathrm{b}$ & $\mathrm{b}$ \\
\hline \multicolumn{3}{|l|}{4 Innovation finance, output and markets } \\
\hline Share of high-tech venture capital investment & $\mathrm{X}$ & \\
\hline Share of early stage venture capital in GDP & $\mathrm{x}$ & \\
\hline Sales of 'new to market' products (\% of all turnover) & $\mathrm{b}$ & $\mathrm{b}$ \\
\hline $\begin{array}{l}\text { Sales of 'new to the firm but not new to the market' products (\% of all } \\
\text { turnover) }\end{array}$ & $\mathrm{b}$ & $\mathrm{b}$ \\
\hline Internet access/ use (composite of home and firms' internet access) & $\mathrm{b}$ & $\mathrm{b}$ \\
\hline ICT expenditures (\% of GDP) & $\mathrm{b}$ & $\mathrm{b}$ \\
\hline Share of manufacturing value-added in high-tech & $\mathrm{X}$ & \\
\hline $\begin{array}{l}\text { Legend: } \\
\text { X: only relevant } \\
\text { x: mainly relevant } \\
\text { b: relevant for both types } \\
\text { Source: own compilation, drawing on the detailed definition of indicators, E } \\
\text { Notes: Public R\&D expenditures do not equal to GERD - BERD; rather, it sl } \\
\text { funded parts of BERD, GOVERD, and HERD }\end{array}$ & 04) & \\
\hline
\end{tabular}


The 2005 European Innovation Scoreboard indicators

\begin{tabular}{|c|c|c|}
\hline & $\begin{array}{c}\text { Relevance } \\
\text { for R\&D- } \\
\text { based } \\
\text { innovation }\end{array}$ & $\begin{array}{c}\text { Relevance } \\
\text { for non- } \\
\text { R\&D- } \\
\text { based } \\
\text { innovation }\end{array}$ \\
\hline \multicolumn{3}{|l|}{1 Innovation drivers } \\
\hline $\begin{array}{l}\text { New S\&E graduates (ISCED 5a and above) per } 1000 \text { population aged } \\
20-29\end{array}$ & $\mathrm{X}$ & \\
\hline Population with tertiary education (\% of $25-64$ years age class) & b & b \\
\hline $\begin{array}{l}\text { Broadband penetration rate (number of broadband lines per } 100 \\
\text { population) }\end{array}$ & $\mathrm{b}$ & $\mathrm{b}$ \\
\hline Participation in life-long learning (\% of $25-64$ years age class) & $\mathrm{b}$ & $\mathrm{b}$ \\
\hline $\begin{array}{l}\text { Youth education attainment level (\% of population aged 20-24 } \\
\text { having completed at least upper secondary education) } \\
2 \text { Knowledge creation }\end{array}$ & $\mathrm{b}$ & $\mathrm{b}$ \\
\hline Public R\&D expenditures (GERD - BERD) (\% of GDP) & $\mathrm{X}$ & \\
\hline Business expenditures on R\&D (BERD) (\% of GDP) & $\mathrm{X}$ & \\
\hline $\begin{array}{l}\text { Share of medium-high-tech and high-tech R\&D (\% of manufacturing } \\
\text { R\&D expenditures) }\end{array}$ & $\mathrm{X}$ & \\
\hline Share of enterprises receiving public funding for innovation & $\mathrm{x}$ & \\
\hline $\begin{array}{l}\text { Share of university R\&D expenditures financed by business sector } \\
3 \text { Innovation \& entrepreneurship }\end{array}$ & $\mathrm{X}$ & \\
\hline SMEs innovating in-house (\% of all SMEs) & $\mathrm{b}$ & $\mathrm{b}$ \\
\hline Innovative SMEs co-operating with others (\% of SMEs) & $\mathrm{b}$ & $\mathrm{b}$ \\
\hline Innovation expenditures (\% of all turnover) & $\mathrm{b}$ & $\mathrm{b}$ \\
\hline Early stage venture capital (\% of GDP) & $\mathrm{x}$ & \\
\hline ICT expenditures (\% of GDP) & $\mathrm{b}$ & $\mathrm{b}$ \\
\hline SMEs using non-technical change (\% of all SMEs) & & $\mathrm{x}$ \\
\hline \multicolumn{3}{|l|}{4 Application } \\
\hline Employment in high-tech services (\% of total workforce) & $\mathrm{X}$ & \\
\hline Exports of high technology products as a share of total exports & $\mathrm{X}$ & \\
\hline Sales of 'new to market' products (\% of all turnover) & b & $\mathrm{b}$ \\
\hline $\begin{array}{l}\text { Sales of 'new to the firm but not new to the market' products (\% of all } \\
\text { turnover) }\end{array}$ & $\mathrm{b}$ & $\mathrm{b}$ \\
\hline $\begin{array}{l}\text { Employment in medium-high and high-tech manufacturing (\% of } \\
\text { total workforce) }\end{array}$ & $\mathrm{X}$ & \\
\hline \multicolumn{3}{|l|}{5 Intellectual property } \\
\hline EPO patents per million population & $\mathrm{x}$ & \\
\hline USPTO patents per million population & $\mathrm{x}$ & \\
\hline Triadic patent families per million population & $\mathrm{x}$ & \\
\hline New community trademarks per million population & $\mathrm{b}$ & $\mathrm{b}$ \\
\hline New community industrial designs per million population & $\mathrm{b}$ & $\mathrm{b}$ \\
\hline
\end{tabular}

Legend:

$\mathrm{X}$ : only relevant

$\mathrm{x}$ : mainly relevant

b: relevant for both types

Source: own compilation, drawing on the detailed definition of indicators, EC (2005)

Notes: Public R\&D expenditures do not equal to GERD - BERD; rather, it should be the sum of government-

funded parts of BERD, GOVERD, and HERD 
The 2006 and 2007 European Innovation Scoreboard indicators

\begin{tabular}{|c|c|c|}
\hline & $\begin{array}{l}\text { Relevance } \\
\text { for } R \& D- \\
\text { based } \\
\text { innovation }\end{array}$ & $\begin{array}{c}\text { Relevance } \\
\text { for non- } \\
\text { R\&D- } \\
\text { based } \\
\text { innovation }\end{array}$ \\
\hline \multicolumn{3}{|l|}{1 Innovation drivers } \\
\hline $\begin{array}{l}\text { New S\&E graduates (ISCED } 5 \text { a and above) per } 1000 \text { population aged } \\
20-29\end{array}$ & $\mathrm{X}$ & \\
\hline Population with tertiary education (\% of 25-64 years age class) & $\mathrm{b}$ & $\mathrm{b}$ \\
\hline $\begin{array}{l}\text { Broadband penetration rate (number of broadband lines per } 100 \\
\text { population) }\end{array}$ & $\mathrm{b}$ & $\mathrm{b}$ \\
\hline Participation in life-long learning (\% of 25-64 years age class) & $\mathrm{b}$ & $\mathrm{b}$ \\
\hline $\begin{array}{l}\text { Youth education attainment level (\% of population aged 20-24 } \\
\text { having completed at least upper secondary education) } \\
2 \text { Knowledge creation }\end{array}$ & $\mathrm{b}$ & $\mathrm{b}$ \\
\hline Public R\&D expenditures (GERD - BERD) (\% of GDP) & $\mathrm{X}$ & \\
\hline Business expenditures on R\&D (BERD) (\% of GDP) & $\mathrm{X}$ & \\
\hline $\begin{array}{l}\text { Share of medium-high-tech and high-tech R\&D (\% of manufacturing } \\
\text { R\&D expenditures) }\end{array}$ & $\mathrm{X}$ & \\
\hline \multicolumn{2}{|l|}{3 Innovation \& entrepreneurship } & \\
\hline SMEs innovating in-house (\% of all SMEs) & $\mathrm{b}$ & $\mathrm{b}$ \\
\hline Innovative SMEs co-operating with others (\% of SMEs) & $\mathrm{b}$ & $\mathrm{b}$ \\
\hline Innovation expenditures (\% of all turnover) & $\mathrm{b}$ & $\mathrm{b}$ \\
\hline Early stage venture capital (\% of GDP) & $\mathrm{x}$ & \\
\hline ICT expenditures (\% of GDP) & $\mathrm{b}$ & $\mathrm{b}$ \\
\hline $\begin{array}{l}\text { SMEs using non-technical change (\% of all SMEs) } \\
4 \text { Application }\end{array}$ & 4 Application & $\mathrm{x}$ \\
\hline Employment in high-tech services (\% of total workforce) & $\mathrm{X}$ & \\
\hline Exports of high technology products as a share of total exports & $\mathrm{X}$ & \\
\hline Sales of 'new to market' products (\% of all turnover) & $\mathrm{b}$ & $\mathrm{b}$ \\
\hline $\begin{array}{l}\text { Sales of 'new to the firm but not new to the market' products (\% of all } \\
\text { turnover) }\end{array}$ & $\mathrm{b}$ & $\mathrm{b}$ \\
\hline $\begin{array}{l}\text { Employment in medium-high and high-tech manufacturing (\% of } \\
\text { total workforce) }\end{array}$ & $\mathrm{X}$ & \\
\hline \multicolumn{3}{|l|}{5 Intellectual property } \\
\hline EPO patents per million population & $\mathrm{x}$ & \\
\hline USPTO patents per million population & $\mathrm{x}$ & \\
\hline Triadic patent families per million population & $\mathrm{x}$ & \\
\hline New community trademarks per million population & $\mathrm{b}$ & $\mathrm{b}$ \\
\hline New community industrial designs per million population & $\mathrm{b}$ & $\mathrm{b}$ \\
\hline $\begin{array}{l}\text { Legend: } \\
\text { X: only relevant } \\
\text { x: mainly relevant } \\
\text { b: relevant for both types } \\
\text { Source: own compilation, drawing on the list of indicators, MERIT and EC JI } \\
\text { Notes: Public R\&D expenditures do not equal to GERD - BERD; rather, it sh } \\
\text { funded parts of BERD. GOVERD and HERD }\end{array}$ & $\begin{array}{l}\text { 2006) } \\
\text { d be the st }\end{array}$ & ht- \\
\hline
\end{tabular}


The 2008 European Innovation Scoreboard indicators

\begin{tabular}{|c|c|c|}
\hline & $\begin{array}{l}\text { Relevance } \\
\text { for } R \& D- \\
\text { based } \\
\text { innovation }\end{array}$ & $\begin{array}{l}\text { Relevance } \\
\text { for non- } \\
\text { R\&D- } \\
\text { based } \\
\text { innovation }\end{array}$ \\
\hline \multicolumn{3}{|l|}{ 1.1 Human resources } \\
\hline $\begin{array}{l}\text { S\&E and SSH graduates per } 1000 \text { population aged 20-29 (first stage of } \\
\text { tertiary education) }\end{array}$ & $\mathrm{x}$ & \\
\hline $\begin{array}{l}\text { S\&E and SSH doctorate graduates per } 1000 \text { population aged 20-29 (second } \\
\text { stage of tertiary education) }\end{array}$ & $\mathrm{x}$ & \\
\hline Population with tertiary education (\% of 25-64 years age class) & $\mathrm{b}$ & $\mathrm{b}$ \\
\hline Participation in life-long learning (\% of 25-64 years age class) & $\mathrm{b}$ & $\mathrm{b}$ \\
\hline $\begin{array}{l}\text { Youth education attainment level (\% of population aged 20-24 having } \\
\text { completed at least upper secondary education) }\end{array}$ & $\mathrm{b}$ & $\mathrm{b}$ \\
\hline \multicolumn{3}{|l|}{ 1.2 Finance and support } \\
\hline Public R\&D expenditures (GERD - BERD) (\% of GDP) & $\mathrm{X}$ & \\
\hline Venture capital (\% of GDP) & $\mathrm{x}$ & \\
\hline Private credit (relative to GDP) & $\mathrm{b}$ & $\mathrm{b}$ \\
\hline Broadband access by firms (\% of firms) & $\mathrm{b}$ & $\mathrm{b}$ \\
\hline \multicolumn{3}{|l|}{ 2.1 Firm investments } \\
\hline Business expenditures on R\&D (BERD) (\% of GDP) & $\mathrm{X}$ & \\
\hline IT expenditures (\% of GDP) & $\mathrm{b}$ & $\mathrm{b}$ \\
\hline Non-R\&D innovation expenditures (\% of turnover) & & $\mathrm{x}$ \\
\hline \multicolumn{3}{|l|}{ 2.2 Linkages \& entrepreneurship } \\
\hline SMEs innovating in-house (\% of all SMEs) & $\mathrm{b}$ & $\mathrm{b}$ \\
\hline Innovative SMEs collaborating with others (\% of SMEs) & $\mathrm{b}$ & $\mathrm{b}$ \\
\hline Firm renewal (SME entries plus exits) (\% of SMEs) & $\mathrm{b}$ & $\mathrm{b}$ \\
\hline Public-private co-publications per million population & $\mathrm{X}$ & \\
\hline \multicolumn{3}{|l|}{ 2.3 Throughputs } \\
\hline EPO patents per million population & $\mathrm{x}$ & \\
\hline Community trademarks per million population & $\mathrm{b}$ & $\mathrm{b}$ \\
\hline Community designs per million population & $\mathrm{b}$ & $\mathrm{b}$ \\
\hline Technology Balance of Payments flows (\% of GDP) & $\mathrm{X}$ & \\
\hline \multicolumn{3}{|l|}{ 3.1 Innovators } \\
\hline SMEs introducing product or process innovations (\% of SMEs) & $\mathrm{b}$ & $\mathrm{b}$ \\
\hline SMEs introducing marketing or organisational innovations (\% of SMEs) & & $\mathrm{X}$ \\
\hline $\begin{array}{l}\text { Resource efficiency innovators [unweighted average of: Share of innovators } \\
\text { where innovation has significantly reduced labour costs (\% of firms) and } \\
\text { Share of innovators where innovation has significantly reduced the use of } \\
\text { materials and energy (\% of firms)] }\end{array}$ & $\mathrm{b}$ & $\mathrm{b}$ \\
\hline \multicolumn{3}{|l|}{ 3.2 Economic effects } \\
\hline $\begin{array}{l}\text { Employment in medium-high and high-tech manufacturing (\% of total } \\
\text { workforce) }\end{array}$ & $\mathrm{X}$ & \\
\hline Employment in knowledge-intensive services (\% of total workforce) & $\mathrm{X}$ & \\
\hline Medium and high-tech manufacturing exports (\% of total exports & $\mathrm{X}$ & \\
\hline Knowledge-intensive services exports (\% of total services exports) & $\mathrm{X}$ & \\
\hline New-to-market sales (\% of turnover) & $\mathrm{b}$ & $\mathrm{b}$ \\
\hline New-to-firm sales (\% of turnover) & $\mathrm{b}$ & $\mathrm{b}$ \\
\hline
\end{tabular}

Legend:

$\mathrm{X}$ : only relevant

$\mathrm{x}$ : mainly relevant

b: relevant for both types

Source: own compilation, drawing on the list of indicators, EC (2009a)

Notes: Public R\&D expenditures do not equal to GERD - BERD; rather, it should be the sum of governmentfunded parts of BERD, GOVERD, and HERD 
The 2009 European Innovation Scoreboard indicators

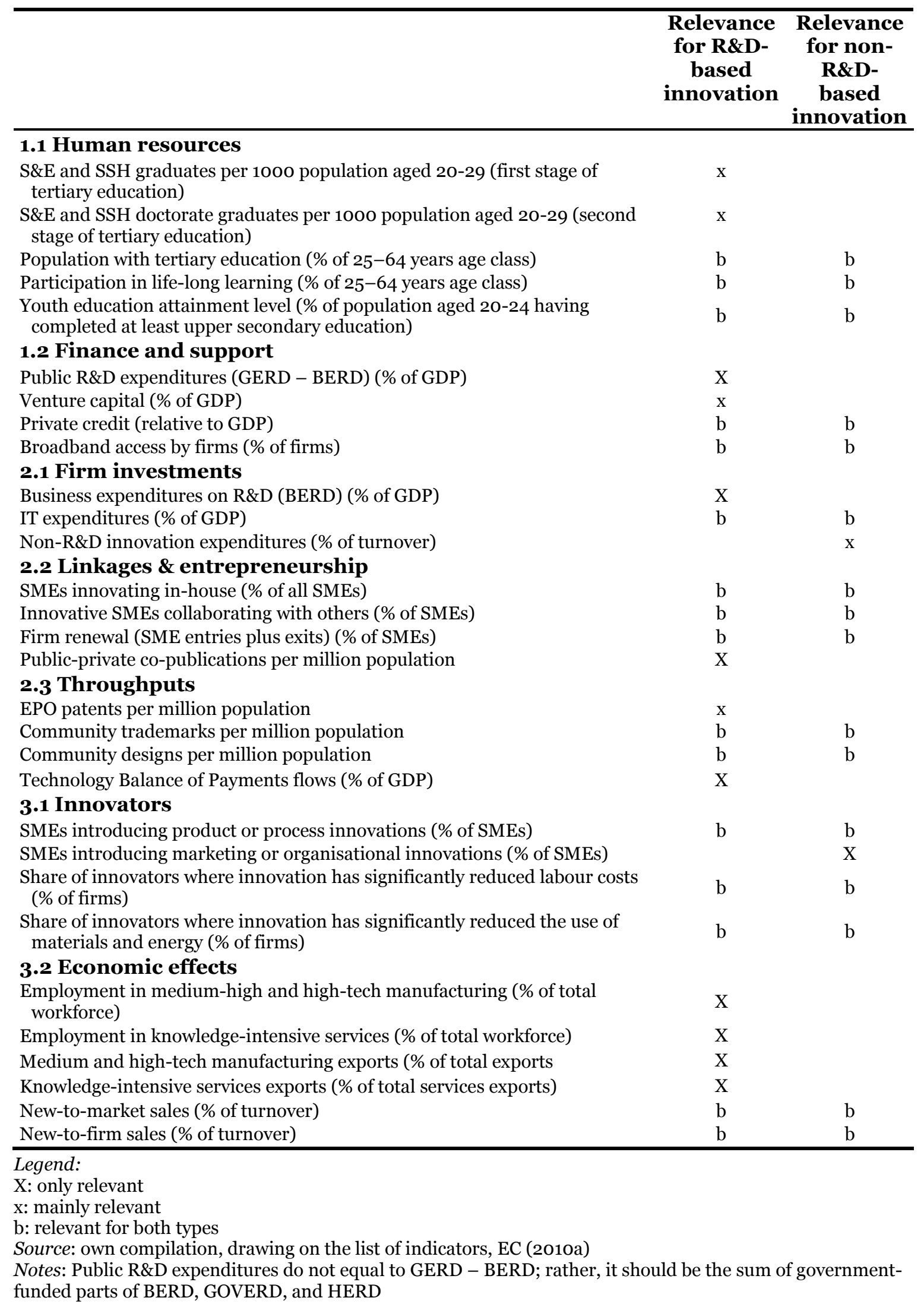


The 2010, 2011, and 2013 Innovation Union Scoreboard indicators

\begin{tabular}{|c|c|c|}
\hline & $\begin{array}{c}\text { Relevance } \\
\text { for R\&D- } \\
\text { based } \\
\text { innovation }\end{array}$ & $\begin{array}{c}\text { Relevance } \\
\text { for non- } \\
\text { R\&D- } \\
\text { based } \\
\text { innovation }\end{array}$ \\
\hline \multicolumn{3}{|l|}{ 1.1 Human resources } \\
\hline New doctorate graduates (ISCED 6) per 1000 population aged 25-34 & $\mathrm{X}$ & \\
\hline $\begin{array}{l}\text { Percentage population aged 30-34 having completed tertiary } \\
\text { education }\end{array}$ & $\mathrm{b}$ & $\mathrm{b}$ \\
\hline $\begin{array}{l}\text { Percentage youth aged } 20-24 \text { having attained at least upper } \\
\text { secondary level education }\end{array}$ & $\mathrm{b}$ & $\mathrm{b}$ \\
\hline \multicolumn{3}{|l|}{ 1.2 Open, excellent and attractive research systems } \\
\hline International scientific co-publications per million population & $\mathrm{X}$ & \\
\hline $\begin{array}{l}\text { Scientific publications among the top } 10 \% \text { most cited publications } \\
\text { worldwide as \% of total scientific publications of the country }\end{array}$ & $\mathrm{X}$ & \\
\hline $\begin{array}{l}\text { Non-EU doctorate studentsi as a \% of all doctorate students } \\
\text { 1.3 Finance and support }\end{array}$ & $\mathrm{X}$ & \\
\hline $\mathrm{R} \& \mathrm{D}$ expenditure in the public sector as \% of GDP & $\mathrm{X}$ & \\
\hline $\begin{array}{l}\text { Venture capital investment as \% of GDP } \\
\text { 2.1 Firm investments }\end{array}$ & 2.1 Firm investments & \\
\hline $\mathrm{R} \& \mathrm{D}$ expenditure in the business sector as \% of GDP & $\mathrm{X}$ & \\
\hline $\begin{array}{l}\text { Non-R\&D innovation expenditures as \% of turnover } \\
\text { 2.2 Linkages \& entrepreneurship }\end{array}$ & & $\mathrm{X}$ \\
\hline SMEs innovating in-house as \% of SMEs & $\mathrm{b}$ & $\mathrm{b}$ \\
\hline Innovative SMEs collaborating with others as \% of SMEs & $\mathrm{b}$ & $\mathrm{b}$ \\
\hline & 2.3 Intellectual assets & \\
\hline PCT patents applications per billion GDP (in PPS€) & $\mathrm{X}$ & \\
\hline $\begin{array}{l}\text { PCT patent applications in societal challenges per billion GDP (in } \\
\text { PPS€) (environment-related technologies; health) }\end{array}$ & $\mathrm{X}$ & \\
\hline Community trademarks per billion GDP (in PPS€) & & $\mathrm{X}$ \\
\hline Community designs per billion GDP (in PPS€) & & $\mathrm{X}$ \\
\hline \multicolumn{3}{|l|}{ 3.1 Innovators } \\
\hline SMEs introducing product or process innovations as \% of SMEs & $\mathrm{b}$ & $\mathrm{b}$ \\
\hline $\begin{array}{l}\text { SMEs introducing marketing or organisational innovations as \% of } \\
\text { SMEs }\end{array}$ & & $\mathrm{X}$ \\
\hline \multicolumn{3}{|l|}{ 3.2 Economic effects } \\
\hline $\begin{array}{l}\text { Employment in knowledge-intensive activities (manufacturing and } \\
\text { services) as \% of total employment }\end{array}$ & $\mathrm{x}$ & \\
\hline $\begin{array}{l}\text { Contribution of medium and high-tech product exports to the trade } \\
\text { balance }\end{array}$ & $\mathrm{x}$ & \\
\hline Knowledge-intensive services exports as \% total service exports & $\mathrm{x}$ & \\
\hline Sales of new to market and new to firm innovations as \% of turnover & $\mathrm{b}$ & $\mathrm{b}$ \\
\hline License and patent revenues from abroad as \% of GDP & $\mathrm{X}$ & \\
\hline
\end{tabular}

Legend:

$\mathrm{X}$ : only relevant

$\mathrm{x}$ : mainly relevant

b: relevant for both types

Source: own compilation, drawing on the detailed definition of indicators, Hollanders and Tarantola (2011)

${ }^{\mathrm{i}}$ It is a somewhat strict definition of openness, which only takes into account non-EU doctorate students. 


\section{APPENDIX 3: THE GLOBAL INNOVATION INDEX INDICATORS}

The first, 2007 edition of the GII has been composed of the following indicators, grouped into eight "pillars", of which 5 meant to represent inputs, while 3 were to reflect on outputs:

\section{INPUTS}

\section{Institutions and Policies}

Independence of judiciary

Demanding regulatory standards

Prevalence of laws relating to ICT

Quality of IPR

Soundness of banks

Quality of scientific research institutions institution

Quality of management/business schools Legal obstacles to foreign labour

Time required to start a business

Time required to obtain licenses

Rigidity of employment index

Investor protection index

ICT priority for government

Human Capacity

Brain drain

Quality of human resource approach

Quality of maths and science education

Graduates in engineering

Graduates in science

Population 15-64

Urban population

Schools connected to the internet

General and ICT Infrastructure

Quality of general infrastructure

Quality of national transport network

Quality of air transport

Fixed line penetration

Mobile penetration

Internet penetration

International bandwidth

ICT expenditure

Personal computer penetration

Mobile price basket

[The quality of organisations is not an

("rule of the game"); A.H.]

[Same as above; A.H.]
[At best indirectly - and vaguely - related to human capacity; A.H.]]

Business, Markets and Capital Flows

Access to loans

Sophistication of financial markets

Issuing shares in local share market

Corporate governance

Buyer sophistication

Customer orientation of firms

Domestic credit to private sector

FDI net inflows

Gross private capital flows

[This is access to infrastructure; A.H.] 
Gross capital formation

Extent of clusters

Commercial services imports

Manufactured imports

Private investment in ICT

Informal economy estimate

[Why among these indicators? A.H.]

Technology and Process Sophistication

Country's level of technology

E-Participation index

E-Government index

Government procurement of advanced technology

Internet use by businesses

Competition among ISP providers

[Why among these indicators? A.H.]

Company technology absorption

Telecom revenue

Secure internet servers per 1,00o people

[Why among these indicators? A.H.]

Spending on R\&D

Royalty and license fee payments

Business/university R\&D collaboration

\section{OUTPUTS}

Knowledge

Local specialised research and training

Nature of competitive advantage

[Not output; A.H.]

Quality of production process technology

[Not output; A.H.]

High-tech exports

[Not output; A.H.]

Manufactured exports

ICT exports

Insurance and financial services

Patents registered (domestic and non-domestic) [Not output; A.H.]

Royalty and license fee receipts

Competitiveness

Growth of exports to neighbouring countries

Intensity of local competition

Reach of exporting in international markets

Commercial services export

Merchandise exports

Goods exported

Service exports

Listed domestic companies

[Why among these indicators? A.H.]

Wealth

Final consumption expenditure

GDP per capita, PPP

GDP growth rate

Industry, value added

Manufacturer, value added

Services, value added

International migration stock

Value of stocks traded

FDI net outflows 